\title{
Variability of the Southeast Pacific Subtropical Anticyclone and its impact on sea surface temperature off north-central Chile
}

\section{Variabilidad del Anticiclón Subtropical del Pacífico Sudeste y su impacto sobre la temperatura superficial del mar frente a la costa centro-norte de Chile}

\author{
Santiago Ancapichún, José Garcés-Vargas* \\ Instituto de Ciencias Marinas y Limnológicas, Facultad de Ciencias, Universidad Austral de Chile, CP 5090000, \\ Valdivia, Chile. \\ * Corresponding author. E-mail: jgarces@docentes.uach.cl
}

\begin{abstract}
The Southeast Pacific Subtropical Anticyclone (SPSA) extends over the entire South Pacific Basin and it is the dominant forcing of the Humboldt Current System. The SPSA has seasonal, interannual, and decadal (interdecadal) variability. The latter variability has been associated with the Pacific Decadal Oscillation (PDO), recognized as a Pan-Pacific mode. However, most of the ocean-atmosphere studies on interdecadal scales have been conducted in the Northern Hemisphere, and very few in the Southern Hemisphere. Thus, through reanalysis model outputs and satellite data, this research mainly establishes the relationship between SPSA and PDO in the period 1949-2012 and its impact on sea surface temperature along the north-central coast of Chile between 2000 and 2012. For this purpose we first analyzed the seasonal and interannual variability of the SPSA. An analysis of correlation between air pressure at sea level and the PDO and Southern Annular Mode (SAM) indices established that, at the interdecadal scale, these oscillations explained $49 \%$ and $40 \%$ of the variance, respectively; however, SAM had a time lag of six years to explain this variance. The PDO, in the air pressure field, produced similar changes to El Niño-Southern Oscillation. Over the past 13 years, the SPSA has intensified and shifted toward the southwest, increasing the offshore Ekman transport and Ekman suction, which would explain much of the observed coastal cooling south of $33^{\circ} \mathrm{S}$ (central Chile).
\end{abstract}

Key words: Southeast Pacific Subtropical Anticyclone, coastal jet, ENSO-like variability, Antarctic oscillation, upwelling.

Resumen. El Anticiclón Subtropical del Pacífico Sudeste (ASPS) se extiende sobre toda la cuenca oceánica del Pacífico Sur y es el forzamiento dominante del Sistema de la Corriente de Humboldt. El ASPS presenta variabilidades estacionales, interanuales y decadales (interdecadales). Esta última variabilidad se ha asociado a la Oscilación Decadal del Pacífico (ODP), reconocida como un modo de la cuenca del Pacífico. Sin embargo, la mayoría de los estudios sobre la relación entre el océano y la atmósfera a escala interdecadal han sido conducidos en el hemisferio norte, y muy pocos en el hemisferio sur. Así, a través de información de salida de modelos de reanálisis y datos satelitales, esta investigación establece principalmente la relación entre el ASPS y la ODP en el periodo 1949-2012 y su repercusión en la temperatura superficial del mar a lo largo de la costa centro-norte de Chile entre 2000 y 2012. Para esto, primero se analizó la variabilidad estacional e interanual del ASPS. Mediante un análisis de correlación entre el campo de presión del aire a nivel de mar y los índices de la ODP y el Modo Anular del Sur (MAS), se estableció que a escala interdecadal éstas oscilaciones explicaron el $49 \%$ y $40 \%$ de la varianza, respectivamente; sin embargo, el MAS presentó un desfase de seis años para explicar esa varianza. La ODP, en el campo de la presión del aire, produjo cambios parecidos a los de El Niño-Oscilación del Sur. En los últimos 13 años, el ASPS se ha intensificado y dirigido hacia el suroeste, incrementando el transporte de Ekman hacia afuera de la costa y la succión de Ekman, lo cual explicaría gran parte la disminución de la temperatura superficial del mar observada hacia el sur de $33^{\circ} \mathrm{S}$ (costa central de Chile).

Palabras clave: Anticiclón Subtropical del Pacífico Sudeste, chorro costero, variabilidad parecida a ENOS, oscilación antártica, afloramiento.

\section{INTRODUCTION}

The circulation in the surface layer of large subtropical gyres is mainly driven by the winds (Huang and Russell 1994) flowing around high pressure centers known as anticyclones. The vertical and horizontal motion in these gyres plays a fundamental role in controlling the ocean-atmosphere interaction, and is of importance for our understanding of the oceanic general circulation and climate variability at different time scales. In the South Pacific Basin, the Southeast Pacific Subtropical Anticyclone (SPSA) is the dominant forcing of the subtropical gyre, which in its right flank is formed by the

\section{INTRODUCCIÓN}

La circulación en la capa superficial de los grandes giros es conducida principalmente por el viento (Huang y Russell 1994) que gira alrededor de los centros de alta presión llamados anticiclones. El movimiento vertical y horizontal en estos giros cumple un rol fundamental en el control de la interacción entre el océano y la atmósfera, y es de gran importancia para la comprensión de la circulación oceánica general y la variabilidad climática a diferentes escalas de tiempo. En la cuenca del Pacífico Sur, el Anticiclón Subtropical del Pacífico Sudeste (ASPS) es el forzamiento dominante del 
southeastern Pacific current system consisting of the Humboldt jet-like stream, Humboldt Current oceanic branch, Humboldt Current coastal branch, Peru-Chile Countercurrent, Peru-Chile Subsurface Current, Chile Coastal Current, South Pacific Current, and South Equatorial Current (Strub et al. 1998, Fuenzalida et al. 2008).

The SPSA has seasonal, interannual, and decadal (interdecadal) cycles. At the seasonal scale, in the austral summer the SPSA is more intense off the coast of central-southern Chile (approximately $35^{\circ} \mathrm{S}$ ) and in winter it is more intense off the coast of La Serena (northern Chile, approximately $30^{\circ} \mathrm{S}$ ) (Taljaard 1972). Along the coast of Peru, the SPSA generates upwelling-favorable winds that are more intense in winter than in summer. These alongshore coastal winds advect water northwards and cause offshore Ekman transport, with the consequent upwelling of water from deeper layers (Croquette et al. 2007). The seasonal wind pattern shows low variability between $18^{\circ}$ and $28^{\circ} \mathrm{S}$ (Pizarro et al. 1994) and an increase between $30^{\circ}$ and $40^{\circ} \mathrm{S}$ (fig. 1), even promoting downwelling during winter (Garreaud and Muñoz 2005, Sobarzo et al. 2007). When the SPSA is stronger the magnitude of the southerly winds increases and so does the transport of water from the pole and the occurrence of upwelling (Croquette et al. 2007). Conversely, when it weakens, the magnitude of the southerly winds decreases and Ekman transport occurs less frequently.

At the interannual scale, during the warm phase of El Niño-Southern Oscillation (ENSO), the intensity of SPSA diminishes, and in the southeastern Pacific, upwelling brings less cold water to the surface due to the deepening of the thermocline (e.g., Blanco et al. 2002, Carr et al. 2002). Moreover, there is less equatorward advection of waters which may be transported poleward as occurred during the 1997-1998 El Niño (Carr et al. 2002). Both mechanisms tend to warm coastal surface waters. During the cold phase of ENSO (La Niña), the intensity of SPSA increases and the oceanographic conditions are opposite to those of El Niño.

The decadal (interdecadal) scale is associated with a PanPacific mode known as the Pacific Decadal Oscillation (PDO) (Deser et al. 2010), Pacific Interdecadal Oscillation (Power et al. 1999, England et al. 2014), or ENSO-like variability (Zhang et al. 1997). This oscillation initially referred to an ocean-atmosphere climate variability centered over the middle latitudes of the North Pacific Basin (Mantua et al. 1997), but it has been extended to the South Pacific (Montecinos et al. 2003, Shakun and Shaman 2009). During the PDO warm (cold) phase there are negative (positive) sea surface temperature (SST) anomalies and a strengthening (weakening) of the westerly wind stress in the central North Pacific that coincide with positive (negative) SST anomalies along the coasts of North and South America (Mantua and Hare 2002) (fig. 2a).

The oscillation known as the Southern Annular Mode (SAM) has interannual and interdecadal variability and giro subtropical, el cual en su flanco derecho está constituido por el sistema de las corrientes del Pacífico sudeste conformado por la corriente de chorro de Humboldt, corriente oceánica de Humboldt, corriente costera de Humboldt, contracorriente Perú-Chile, corriente subsuperficial PerúChile, corriente costera de Chile, corriente del Pacífico Sur y corriente ecuatorial del Sur (Strub et al. 1998, Fuenzalida et al. 2008).

El ASPS tiene ciclos estacionales, interanuales y decadales (interdecadales). A escala estacional, en el verano austral, el ASPS es más intenso frente a la costa centro-sur de Chile (aproximadamente $35^{\circ} \mathrm{S}$ ) y en invierno es más intenso frente a la costa de La Serena (norte de Chile, aproximadamente $30^{\circ} \mathrm{S}$ ) (Taljaard 1972). Frente a las costas del Perú, el ASPS provoca vientos favorables a la surgencia que son más intensos en el invierno que en el verano. Estos vientos paralelos a la costa advectan agua hacia el norte y ocasionan un transporte de Ekman costa afuera, y se genera un consecuente afloramiento de estratos más profundos (Croquette et al. 2007). El patrón estacional de los vientos tiene una variabilidad baja entre los $18^{\circ}$ y $28^{\circ} \mathrm{S}$ (Pizarro et al. 1994), mientras que entre los $30^{\circ}$ y $40^{\circ} \mathrm{S}$, esta variabilidad se incrementa (fig. 1) e incluso promueve hundimiento durante el invierno (Garreaud y Muñoz 2005, Sobarzo et al. 2007). Cuando el ASPS se fortalece, se incrementa la magnitud de los vientos provenientes del sur y, por tanto, hay un mayor transporte de aguas del polo y más eventos de surgencia (Croquette et al. 2007). Por el contrario, al debilitarse el ASPS, los vientos provenientes del sur decrecen en magnitud y la incidencia del transporte de Ekman es menor.

A escala interanual, durante la fase cálida de El NiñoOscilación del Sur (ENOS), la intensidad del ASPS disminuye, y en el Pacífico sudeste, la surgencia lleva aguas menos frías hacia la superficie debido a que la termoclina se profundiza (e.g., Blanco et al. 2002, Carr et al. 2002). Además, también ocurre una menor advección de aguas hacia el ecuador que incluso podrían dirigirse hacia el polo, como lo ocurrido durante El Niño 1997-1998 (Carr et al. 2002). Ambos mecanismos tienden a calentar las aguas superficiales costeras. Durante la fase fría de ENOS (La Niña), la intensidad del ASPS aumenta y ocurren condiciones oceanográficas opuestas a El Niño.

La escala decadal (interdecadal) es asociada con un modo de la cuenca del Pacífico conocido comúnmente como Oscilación Decadal del Pacífico (ODP) (Deser et al. 2010), Oscilación Interdecadal del Pacífico (Power et al. 1999, England et al. 2014) o varibilidad parecida a ENOS (Zhang et al. 1997). Esta oscilación inicialmente se refería a una variabilidad climática océano-atmósfera centrada sobre las latitudes medias de la cuenca del Pacífico Norte (Mantua et al. 1997), pero se ha reconocido su extensión hacia el Pacífico Sur (Montecinos et al. 2003, Shakun y Shaman 2009). Durante la fase cálida (fría) de la ODP, se presentan anomalías negativas (positivas) de temperatura superficial del mar (TSM) y un reforzamiento (debilitamiento) del 


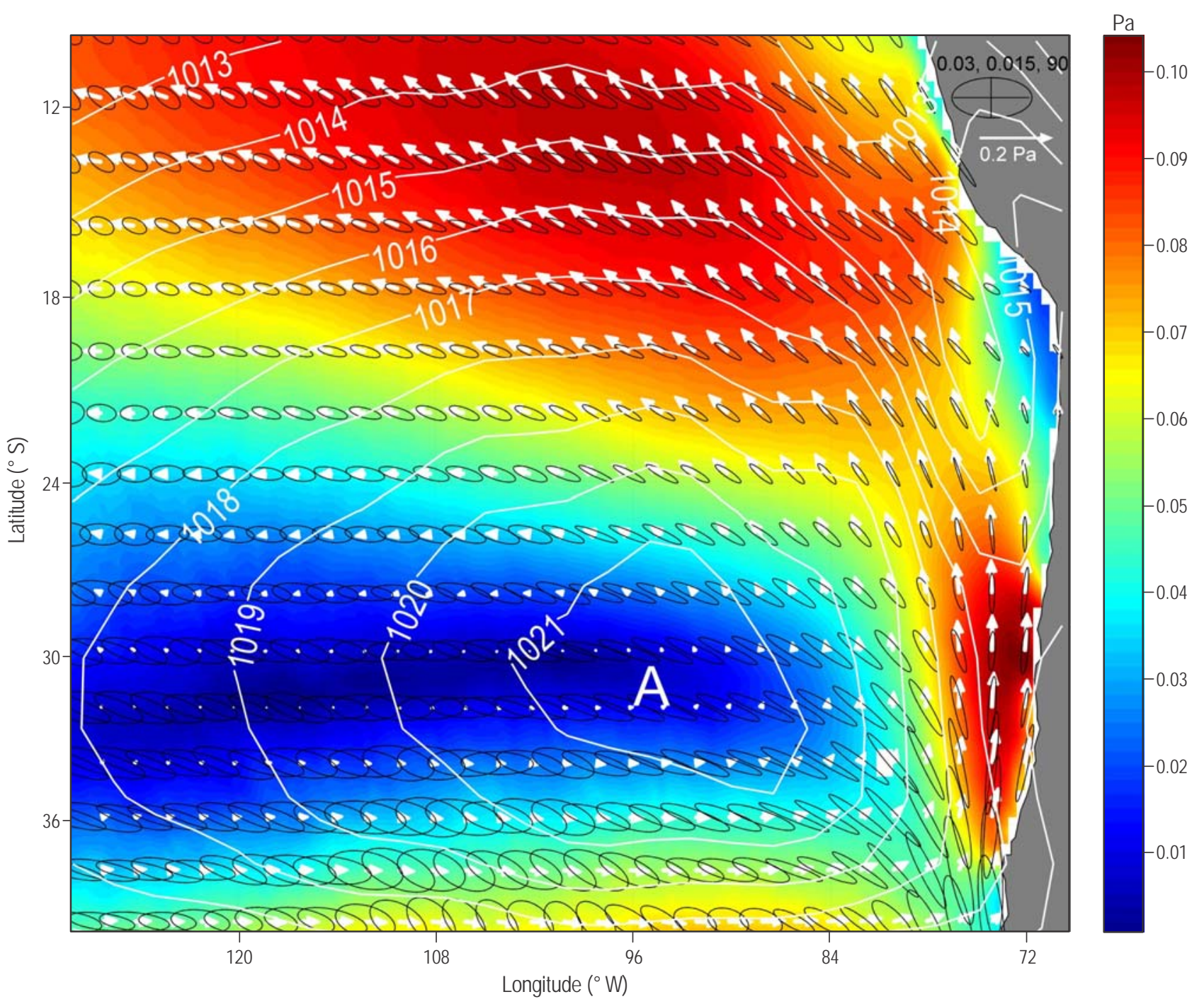

Figure 1. Magnitude (color) and direction (vectors) of the annual mean wind stress in the eastern Pacific Ocean based on QuickSCAT (Piolle and Bentamy 2002). The ellipses show the variance of the monthly wind stress climatology. The contours show the annual mean air pressure at sea level (hPa) based on NCEP/NCAR (Kalnay et al. 1996). The scale for wind stress direction and the variance ellipses are shown in the upper right-hand corner. The scale of the ellipse represents a major axis of $0.03 \mathrm{~Pa}$ and a minor axis of $0.015 \mathrm{~Pa}$, and it rotates $90^{\circ}$ from the north. The letter A represents the annual center of the Southeast Pacific Subtropical Anticyclone.

Figura 1. Magnitud (color) y dirección (vectores) del promedio anual del esfuerzo del viento en el Pacífico oriental con base en QuickSCAT (Piolle y Bentamy 2002). Las elipses muestran la varianza de la climatología mensual del esfuerzo del viento. Los contornos muestran el promedio anual de la presión del aire a nivel del mar (hPa) con base en NCEP/NCAR (Kalnay et al. 1996). La escala para la dirección del esfuerzo del viento y las elipses de varianza se muestran en la esquina superior derecha. La escala de la elipse representa un eje mayor de $0.03 \mathrm{~Pa}$ y un eje menor de $0.015 \mathrm{~Pa}$, y la elipse rota $90^{\circ}$ desde el norte. La A representa el centro anual del Anticiclón Subtropical del Pacífico Sudeste.

affects the South Pacific Ocean. It has been described as a large-scale alternation of atmospheric mass between the midand high-latitude surface pressure (Gong and Wang 1999). At the interdecadal scale, when SAM is in its positive phase, the westerly winds strengthen $\left(65^{\circ} \mathrm{S}\right.$ southward, fig. $\left.2 \mathrm{~b}\right)$ and there is an increase in northward Ekman transport. SAM is also associated with the divergence of surface transport near Antarctica and acceleration of the Circumpolar Current. Further north, around $40^{\circ} \mathrm{S}$, this oscillation produces an esfuerzo de los vientos del oeste en la parte central del Pacífico Norte que coinciden con anomalías positivas (negativas) de TSM a lo largo de las costas de América del Norte y Sur (Mantua y Hare 2002) (fig. 2a).

El Modo Anular del Sur (MAS) es una oscilación que tiene variabilidad interanual e interdecadal y que afecta el océano Pacífico Sur. Esta oscilación es descrita como una alternación a gran escala de la masa atmosférica de la presión superficial entre las latitudes medias y altas (Gong y Wang 

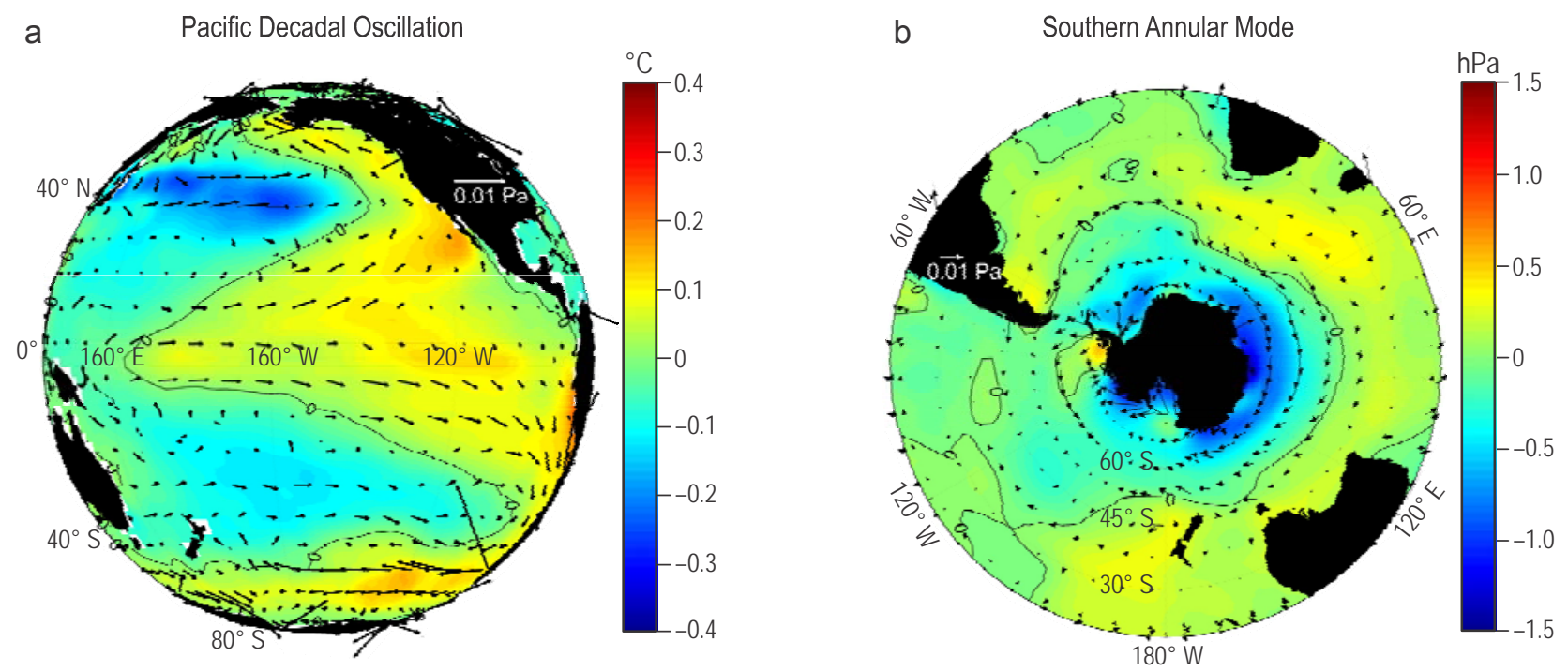

Figure 2. Mean anomalies of the spatial climate variability associated with the warm phase of (a) the Pacific Decadal Oscillation (1975-1998) and (b) the Southern Annular Mode (1993-2001). Sea surface temperature (SST, $\left.{ }^{\circ} \mathrm{C}\right)$ is shown in (a) and air pressure at sea level (AP, hPa) is shown in (b). The vectors represent wind stress. The mean of all point anomalies was multiplied by the mean of the climate anomaly associated with each index. The AP and wind stress data were obtained from NCEP/NCAR (Kalnay et al. 1996) and the SST data from ERSST v3b (Smith et al. 2008), and their anomalies were based on the climatology for the period 1949-2012.

Figura 2. Promedio de las anomalías de la variabilidad espacial climática asociada a la fase cálida de (a) la Oscilación Decadal del Pacífico (1975-1998) y (b) el Modo Anular del Sur (1993-2001). En (a) se muestra la temperatura superficial del mar (TSM, $\left.{ }^{\circ} \mathrm{C}\right)$ y en (b) la presión del aire a nivel del mar (PA, hPa). Los vectores representan el esfuerzo del viento. El promedio de las anomalías en cada punto se multiplicó por el promedio de la anomalía climática asociada a cada índice. Los datos de PA y el esfuerzo del viento fueron obtenidos de NCEP-NCAR (Kalnay et al. 1996) y los datos de TSM de ERSST v3b (Smith et al. 2008), y sus anomalías fueron basadas en la climatología del periodo 1949-2012.

increase in the convergence of Ekman, SST, and westward fluxes (Hall and Visbeck 2002).

On the west coast of South America, PDO is associated with SST anomalies originating from atmospheric forcing that advects waters from the subtropical gyre en route to the tropics (White and Cayan 1998). In this respect, there is evidence of a decrease in the southeastern Pacific SST in recent decades (Willis et al. 2004, Schneider et al. 2007, Falvey and Garreaud 2009) that has been related to an acceleration of the circulation of the subtropical gyre. This acceleration is caused by the intensification in wind stress (Roemmich et al. 2007, Schneider et al. 2007) linked to the strengthening of the SPSA (Falvey and Garreaud 2009).

The main interannual and interdecadal changes in SST along the coast of north-central Chile have been associated with ENSO and PDO, respectively. The ENSO-related variability decreases towards the poles, whereas the interdecadal variability increases towards subtropical regions. Both oscillations affect the SPSA pressure field and cause large-scale anomalies in wind magnitude and direction, modifying both the fisheries and the flora and fauna (Yáñez 1991, Hayward 1997, Thiel et al. 2007). Few studies specifically address the interannual and decadal variability of SPSA. A study of the right side of the SPSA, which controls wind-driven upwelling, would provide a better understanding of SST off north-central Chile.
1999). A escala interdecadal, se ha observado que cuando el MAS está en su fase positiva, se fortalecen los vientos provenientes del oeste $\left(65^{\circ} \mathrm{S}\right.$ hacia el sur, fig. $\left.2 \mathrm{~b}\right) \mathrm{y}$, como resultado, hay un incremento del transporte de Ekman hacia el norte. Además, el MAS produce divergencia del transporte superficial cercano a la Antártica y aceleramiento de la corriente circumpolar. Más hacia el norte, alrededor de los $40^{\circ} \mathrm{S}$, esta oscilación produce un incremento en la convergencia de Ekman, la TSM y los flujos hacia el oeste (Hall y Visbeck 2002).

En la costa oeste de Sudamérica, la ODP produce anomalías de TSM, las cuales se originan a través del forzamiento atmosférico que genera advección de aguas provenientes del giro subtropical en su camino hacia los trópicos (White y Cayan 1998). En este sentido, hay evidencias de un decrecimiento en las temperaturas de las aguas superficiales del Pacífico Sudeste en las recientes décadas (Willis et al. 2004, Schneider et al. 2007, Falvey y Garreaud 2009) que han sido relacionadas con una aceleración de la circulación del giro subtropical. Esta aceleración sería causada por la intensificación del esfuerzo del viento (Roemmich et al. 2007, Schneider et al. 2007) ligado al reforzamiento del ASPS (Falvey y Garreaud 2009).

Los principales cambios interanuales e interdecadales de la TSM a lo largo de la costa centro-norte de Chile se han asociado al ciclo ENOS y a la ODP, respectivamente. La 
This paper analyzes the intensity and position of the SPSA on seasonal to interdecadal scales through the study of sea-level pressure and its relation to the ENSO, PDO, and SAM indices in the period 1949-2012. The impact of the fluctuations in wind stress, originated by changes in the SPSA, on the decrease in SST observed in recent years off north-central Chile is also analyzed.

\section{MATERIALS AND METHODS}

\section{Data set}

For this study we used meteorological and oceanographic information on air pressure at sea level for the period 1949-2012, and wind stress magnitude and direction, and SST for the period 2000-2012. We also used information obtained from three indices: PDO, SAM, and Oceanic Niño Index (ONI). Monthy data were used except in the case of SST, where daily data were converted to monthly averages.

\section{Meterological and oceanographic information}

Air pressure at sea level

Sea-level air pressure (AP) data (spatial resolution of $2.5^{\circ} \times 2.5^{\circ}$ ) were generated by the National Centers for Environmental Prediction/National Center for Atmospheric Research (NCEP/NCAR) Reanalysis Project. This project consists of a physical model subjected to permanent readjustments through comparisons among in situ and satellite temperature, wind, pressure, and other data (Kalnay et al. 1996).

\section{Surface wind stress}

Monthly surface wind stress magnitude and direction correspond to products developed by the French Research Institute for Exploitation of the Sea (IFREMER). These products were interpolated by the objective method and based on the products derived by the SeaWinds scatterometer on board the QuikSCAT satellite (Piolle and Bentamy 2002) and the advanced scatterometer (ASCAT) on board the MetOp satellites (Bentamy and Fillon 2012). Both products have a spatial resolution of $0.25^{\circ} \times 0.25^{\circ}$.

Data collected by QuikSCAT between January 2000 and November 2009 (when it stopped operating) and by ASCAT between May 2007 (when it began operations) and December 2012 were used. In the overlapping period, the correlation (mean square error) between both data sets was 0.73 (0.0064) for the zonal wind stress and $0.93(0.0086)$ for the meridional component along the coast of north-central Chile $\left(17-40^{\circ} \mathrm{S}\right.$ and the first $100 \mathrm{~km}$ from shore). All correlations had a $95 \%$ significance level. The information given corresponds to QuikSCAT-derived products and to data obtained after November 2009 by linear regression between the two data bases where the independent variables were the ASCATderived products. variabilidad relacionada con ENOS decrece hacia los polos, mientras que la variabilidad interdecadal incrementa hacia las zonas subtropicales. Ambas oscilaciones afectan el campo de presiones del ASPS al producir anomalías en la magnitud y dirección de los vientos a gran escala, modificando tanto las pesquerías como la flora y fauna (Yáñez 1991, Hayward 1997, Thiel et al. 2007). Hay pocos estudios centrados en la variabilidad del ASPS a escala interanual y decadal. Un estudio detallado sobre el flanco derecho del ASPS, el cual controla la surgencia impulsada por el viento, mejorará el entendimiento de la TSM en la parte centro-norte de Chile.

En la presente investigación se realiza un análisis de la intensidad y posición del ASPS desde la escala estacional hasta interdecadal mediante el estudio de la presión a nivel del mar y su relación con los índices ENOS, ODP y MAS en el periodo 1949-2012. Se establece el impacto que tienen las fluctuaciones del esfuerzo del viento, originado por los cambios en el ASPS, en la disminución de la TSM observada en los últimos años a lo largo de la costa centro-norte de Chile.

\section{MATERIALES Y MÉTODOS}

\section{Bases de datos}

Para el presente estudio se utilizó información meteorológica y oceanográfica correspondiente a presión del aire a nivel del mar para el periodo 1949-2012, magnitud y dirección del esfuerzo del viento superficial y TSM para el periodo 2000-2012. Además, se utilizó información sobre tres índices: ODP, MAS e Índice del Niño Oceánico (INO). Se usó información mensual excepto para la TSM, cuyos registros fueron diarios y promediados por mes.

\section{Información meteorológica y oceanográfica}

\section{Presión del aire a nivel del mar}

Los datos de la presión del aire a nivel del mar (PA, resolución espacial de $2.5^{\circ} \times 2.5^{\circ}$ ) proceden del proyecto de reanálisis National Centers for Environmental Prediction/ National Center for Atmospheric Research (NCEP/NCAR). Este proyecto consiste en un modelo físico sometido a reajustes permanentes a través de la comparación entre datos in situ y satelitales de temperatura, vientos, presión y otros (Kalnay et al. 1996).

\section{Esfuerzo del viento superficial}

La magnitud y dirección del esfuerzo del viento superficial mensual corresponden a productos desarrollados por el Instituto Francés de Investigación para la Explotación del Mar (IFREMER). Estos productos fueron interpolados mediante el método objetivo y basados en los obtenidos por los escaterómetros a bordo de los satélites QuikSCAT (sensor SeaWind) (Piolle y Bentamy 2002) y MetOP (sensor 
Variables derived from surface wind stress

Ekman transport perpendicular to the coast $\left(M_{x}, \mathrm{~m}^{2} \mathrm{~s}^{-1}\right)$ and Ekman pumping $\left(W_{e}, \mathrm{~m} \mathrm{~s}^{-1}\right)$ for each point of the wind field component(s) were calculated according to Talley et al. (2011) (equation 1) and Chereskin and Price (2001) (equation 2), respectively:

$$
\begin{gathered}
M_{x}=\frac{1}{\rho f} \tau_{y} \\
W_{e}=\frac{1}{\rho f} \nabla \times \vec{\tau}
\end{gathered}
$$

where $\rho$ is the density of seawater $\left(1026.97 \mathrm{~kg} \mathrm{~m}^{-3}\right)$, $f=2 \Omega \sin \theta$ is the Coriolis parameter (where $\Omega$ is the Earth's angular velocity $\left[7.27 \times 10^{-5} \mathrm{rad} \mathrm{s}^{-1}\right]$ and $\theta$ is the latitude of each grid point), and $\nabla \times \vec{\tau}$ is the wind stress curl. Wind stress curl was calculated by a first-order centered difference scheme, so the grid points closest to shore could not be evaluated.

\section{Sea surface temperature}

Optimum interpolation SST data (spatial resolution of $0.25^{\circ} \times 0.25^{\circ}$ ) were obtained from NOAA/NESDIS/NCDC. They were derived by the Advanced Very High Resolution Radiometer (AVHRR) sensor and adjusted for biases by in situ data from ships and buoys (Reynolds et al. 2007).

\section{Indices}

\section{Oceanic Niño Index}

The ONI is defined as the three-month running mean of SST anomalies in the Niño 3.4 region $\left(5^{\circ} \mathrm{N}-5^{\circ} \mathrm{S}\right.$, $\left.120^{\circ}-170^{\circ} \mathrm{W}\right)$. The anomalies are based on a set of improved homogeneous historical SST analyses of the ERSST.v3b data base (Smith et al. 2008). This index was obtained from NOAA's Climate Prediction Center, and it is the main measure used for monitoring, assessing, and predicting ENSO.

\section{Pacific Decadal Oscillation}

The PDO index results from the analysis of empirical orthogonal functions (EOF) corresponding to standardized values of the first principal component of the SST anomalies in the North Pacific (poleward of $20^{\circ} \mathrm{N}$ ). It was obtained from the Joint Institute for the Study of the Atmosphere and Ocean. Before analyzing the EOF, the monthly global means were subtracted from the SST anomalies to prevent the possible effect of global warming (Mantua et al. 1997).

\section{Southern Annular Mode}

The SAM index, also known as the Antarctic Oscillation, is defined as the difference in zonal mean sea-level pressure
ASCAT) (Bentamy y Fillon 2012). Ambos productos tienen una resolución espacial de $0.25^{\circ} \times 0.25^{\circ}$.

Se utilizó la información registrada por QuikSCAT entre enero de 2000 y noviembre de 2009 (tiempo en que dejó de operar) y por ASCAT entre mayo de 2007 (tiempo en que comenzó a funcionar) y diciembre de 2012. La correlación (error cuadrático medio) entre ambas bases de datos fue de 0.73 (0.0064) para el esfuerzo del viento zonal y 0.93 (0.0086) para la componente meridional en el periodo de superposición a lo largo de la costa centro-norte de Chile $\left(17-40^{\circ} \mathrm{S}\right.$ y los primeros $100 \mathrm{~km}$ de la costa). Todas las correlaciones tuvieron un nivel de significación del 95\%. La información que se presenta corresponde a los productos derivados del satélite QuikSCAT y a los datos obtenidos después de noviembre de 2009 mediante regresión lineal entre las dos bases de datos en donde las variables independientes fueron los productos derivados de ASCAT.

\section{Variables derivadas del esfuerzo del viento superficial}

Se calculó el transporte superficial de Ekman perpendicular a la costa $\left(M_{x}, \mathrm{~m}^{2} \mathrm{~s}^{-1}\right)$ y el bombeo de Ekman $\left(W_{e}, \mathrm{~m} \mathrm{~s}^{-1}\right)$ para cada punto de la(s) componente(s) del campo del viento de acuerdo con Talley et al. (2011) (ecuación 1) y Chereskin y Price (2001) (ecuación 2), respectivamente:

$$
\begin{gathered}
M_{x}=\frac{1}{\rho f} \tau_{y} \\
W_{e}=\frac{1}{\rho f} \nabla \times \vec{\tau}
\end{gathered}
$$

donde $\rho$ es la densidad del agua de mar $\left(1026.97 \mathrm{~kg} \mathrm{~m}^{-3}\right)$, $f=2 \Omega \operatorname{sen} \theta$ es el parámetro de coriolis (donde $\Omega$ es la velocidad angular de la Tierra $\left[7.27 \times 10^{-5} \mathrm{rad} \mathrm{s}^{-1}\right]$ y $\theta$ es la latitud de cada punto de grilla) y $\nabla \times \vec{\tau}$ es el rotor del esfuerzo del viento. El rotor del esfuerzo del viento se calculó mediante diferenciación centrada de primer orden, lo cual implicó que no se pudieron evaluar los puntos de grilla más cercanos a la costa.

\section{Temperatura superficial del mar}

Los datos de TSM procesados mediante interpolación óptima fueron obtenidos de NOAA/NESDIS/NCDC (resolución espacial de $0.25^{\circ} \times 0.25^{\circ}$ ). Estos datos fueron derivados del sensor Advanced Very High Resolution Radiometer (AVHRR) y sus sesgos fueron corregidos con la información in situ procedente de barcos y boyas (Reynolds et al. 2007).

\section{Índices}

Índice del Niño Oceánico

El INO es definido como la media móvil de tres meses de las anomalías de la TSM promedio de la región del Niño 3.4 
between $40^{\circ} \mathrm{S}$ and $65^{\circ} \mathrm{S}$. We used the index calculated by Marshall (2003), who used AP data obtained from the NCEP/ NCAR, ERA-15, and ERA-40 reanalysis models validated against in situ data.

\section{Behavior of the Southeast Pacific Subtropical Anticyclone}

To establish the location and intensity of the SPSA, the AP data for the area of greatest influence $\left(15^{\circ}-50^{\circ} \mathrm{S}\right.$, $150^{\circ}-69^{\circ} \mathrm{W}$ ) were averaged annually and the maximum value was obtained. This maximum annual value was considered the center of the SPSA and was used to establish its latitudinal and longitudinal position over time. To determine whether there were significant differences between the warm and cool phases of the PDO, the time series were separated into both phases according to the PDO index. Both groups were then tested for normality. Student's $t$-test was applied to the groups with normal distribution; otherwise, a MannWhitney rank sum test was applied.

To determine the interannual and interdecadal variability of the SPSA, annual time series were obtained by averaging the monthly AP data for each grid point over the area of greatest influence. The linear trend was removed from these time series and a seven-year running mean was applied twice to obtain the interdecadal time series. The interannual series were generated by subtracting the annual series without the linear trend from the interdecadal series. Both procedures were used in a similar study by Montecinos et al. (2003). Subsequently, the period of the interannual and interdecadal series was reduced to 1953-2010 and 1955-2006, respectively. An EOF analysis was applied to the series obtained (Emery and Thomson 2004). The same method was applied to obtain the interannual time series for the ONI and the interdecadal time series for the PDO and SAM indices. Since the analyzed signals (interannual and interdecadal) could project onto other EOF modes, the interannual and interdecadal AP series were averaged in order to obtain a single representative interannual and interdecadal time series that would be equivalent to the temporal component(s) of the EOF analysis. Moreover, to determine the spatial structure of the AP field and its relation to ENSO (PDO and SAM), a correlation analysis was performed between the interannual (interdecadal) AP series for each grid point and the interannual (interdecadal) series of the ONI (PDO and SAM indices), which would be equivalent to the spatial component(s) of the EOF analysis. The Spearman correlation analysis was used with a greater than $95 \%$ significance level.

Finally, monthly climatologies of the center of the SPSA were produced for all the study period and for the warm and cool PDO phases indicated at http://www.nwfsc.noaa.gov/ research/divisions/fe/estuarine/oeip/ca-pdo.cfm. $\left(5^{\circ} \mathrm{N}-5^{\circ} \mathrm{S}, 120^{\circ}-170^{\circ} \mathrm{W}\right)$. Las anomalías se basan en un conjunto de análisis de TSM históricos homogéneos mejorados de la base datos ERSST.v3b (Smith et al. 2008). Este índice fue obtenido del Climate Prediction Center de la NOAA, y es la medida principal utilizada para el seguimiento, la evaluación y la predicción de ENOS.

\section{Índice de la Oscilación Decadal del Pacífico}

El índice de la ODP es el resultado de un análisis de funciones empíricas ortogonales (FEO) correspondiente a valores estandarizados del primer componente principal de las anomalías de TSM en el Pacífico Norte (desde los $20^{\circ} \mathrm{N}$ hasta el polo). Este índice fue obtenido del Joint Institute for the Study of the Atmosphere and Ocean. Antes de realizar el análisis de FEO, se sustrajeron las medias mensuales globales de las anomalías de TSM para evitar el efecto de un posible calentamiento global (Mantua et al. 1997).

\section{Índice del Modo Anular del Sur}

El índice del MAS, también llamado Oscilación Antártica, es el resultado de la diferencia del promedio zonal de presiones a nivel del mar entre $40^{\circ} \mathrm{S}$ y $65^{\circ} \mathrm{S}$. Se utilizó el índice calculado por Marshall (2003), quien usó información de PA obtenida de los modelos de reanálisis NCEP/NCAR, ERA-15 y ERA-40 validados con información de estaciones in situ.

\section{Comportamiento del Anticiclón Subtropical del Pacífico Sudeste}

Para establecer la ubicación e intensidad del ASPS, se promediaron anualmente los datos de PA para el área de mayor influencia $\left(15^{\circ}-50^{\circ} \mathrm{S}, 150^{\circ}-69^{\circ} \mathrm{W}\right)$ y luego se obtuvo el valor máximo. Este valor máximo anual fue considerado el centro del ASPS y fue utilizado para establecer su posición en latitud y longitud a través del tiempo. Para determinar si existen diferencias significativas entre las fases cálida y fría de la ODP, se separaron las series de tiempo en ambas fases de acuerdo con el índice de la ODP. Luego se aplicó una prueba de normalidad a ambos grupos. Se aplicó una prueba $t$ de Student a los grupos con distribución normal y una prueba de suma de rangos de Mann-Whitney cuando la distribución no fue normal.

Para determinar la variabilidad interanual e interdecadal del ASPS, se obtuvieron series de tiempo anuales promediando los datos mensuales de PA en cada uno de los puntos de grilla sobre el área de mayor influencia. A éstas series de tiempo anuales se les removió la tendencia lineal y luego se les aplicó dos veces un promedio móvil de siete años para obtener series de tiempo interdecadales. Las series de tiempo interanuales se generaron restando las series anuales 
Time series and trends in meteorological and oceanographic variables

Time series were established of the monthly anomalies of SST, Ekman transport perpendicular to the coastline, and Ekman pumping off north-central Chile $\left(17-40^{\circ} \mathrm{S}\right.$ and first $100 \mathrm{~km}$ from shore). A time series of the SPSA intensity anomalies was also established. Each of these time series was adjusted with a linear trend between 2000 and 2012 .

\section{RESULTS}

\section{Seasonal variability of the Southeast Pacific Subtropical Anticyclone}

The seasonal variation in the intensity of the SPSA showed a semiannual behavior with maximum intensity in February and October. In February and March SPSA was located at its southernmost position $\left(\sim 37^{\circ} \mathrm{S}\right)$ and far from the continent $\left(\sim 108^{\circ} \mathrm{W}\right)$, whereas in May, when its intensity was weakest, it reached its northermost position $\left(\sim 26^{\circ} \mathrm{S}\right)$ and was close to the continent $\left(\sim 86^{\circ} \mathrm{W}\right)$ (fig. 3 ).

\section{Interannual and decadal variability at the center of the Southeast Pacific Subtropical Anticyclone in relation to the Pacific Decadal Oscillation}

In general, there was an inverse relationship between the intensity of the SPSA and the PDO: when the intensity of the anticyclone increased, the PDO was in its cool phase and vice versa $(R=-0.45)$ (fig. 4$)$. Conversely, there was a direct correlation between the latitudinal position of the center of the SPSA and the PDO: when the anticyclone center tended to follow an equatorward track, the PDO was in its warm phase and vice versa $(R=-0.32)$ (fig. 4$)$. In addition, a relationship was found between the latitudinal and longitudinal position of the center of the SPSA: when it moved southward it also moved westward $(R=-0.59)$. The significance tests revealed that there were significant differences between the warm and cool phases of the PDO relative to the intensity $(P<0.001)$, latitudinal position $(P=0.011)$, and longitudinal position $(P=0.012)$ of the SPSA, confirming the relationships found.

As shown, there was a strong correlation between the intensity and position of the SPSA and the PDO; however, as the interannual and decadal signals were mixed, the EOF and correlation analyses explained in the methodology were performed. The correlation between the representative interannual AP series and the interannual ONI series showed an inverse relationship $(R=-0.75)$ (fig. 5a). Hence, the main source of interannual variability over this area was ENSO, which explained $57 \%$ of the interannual variance. The spatial structure of the correlation analysis between the interannual AP field and the interannual ONI series revealed an inverse relationship throughout the area, except for a small section located southward of $48^{\circ} \mathrm{S}$. ENSO affected mainly the sin tendencia lineal de las series interdecadales. Ambos procedimientos se realizaron en una investigación similar por Montecinos et al. (2003). Después de estos procesos, el periodo de las series interanuales e interdecadales se redujo a 1953-2010 y 1955-2006, respectivamente. A las series obtenidas se les aplicó un análisis de FEO (Emery y Thomson 2004). Se aplicó la misma técnica para obtener la serie de tiempo interanual del INO y las series de tiempo interdecadales de los índices ODP y MAS. Debido a que las señales analizadas (interanual e interdecadal) podrían proyectarse sobre otros modos de FEO, se promediaron las series interanuales e interdecadales de PA para obtener una sola serie de tiempo interanual e interdecadal representativa del campo analizado, lo cual equivaldría a la(s) componente(s) temporal(es) del análisis de FEO. Además, para obtener la estructura espacial del campo de PA y su relación con ENOS (ODP y MAS), se realizó un análisis de correlación entre las series interanuales (interdecadales) de PA de cada uno de los puntos de la grilla y la serie interanual (interdecadal) del (de los) INO (índices de la ODP y MAS), lo cual sería semejante al (los) componente(s) espacial(es) del análisis de FEO. Se utilizó el ánalisis de correlación de Sperman con un nivel de significación mayor que $95 \%$.

Finalmente, se realizaron climatologías mensuales del centro del ASPS para todo el periodo de estudio y para los años de fase cálida y fase fría de la ODP señalados en la página de internet http://www.nwfsc.noaa.gov/research/divisions/fe/estuarine/oeip/ca-pdo.cfm.

\section{Series de tiempo y tendencias de variables meteorológicas y oceanográficas}

Se establecieron series de tiempo de las anomalías mensuales de la TSM, del transporte superficial de Ekman perpendicular a la costa y del bombeo de Ekman a lo largo de la costa centro-norte de Chile $\left(17-40^{\circ} \mathrm{S}\right.$ y los primeros $100 \mathrm{~km}$ de la costa). Además, se estableció una serie de tiempo mensual de las anomalías de la intensidad del ASPS. A cada una de éstas series de tiempo se le ajustó una tendencia lineal entre 2000 y 2012.

\section{RESULTADOS}

\section{Variabilidad estacional del Anticiclón Subtropical del Pacífico Sudeste}

La variabilidad estacional de la intensidad del ASPS mostró un comportamiento semianual con una intensidad máxima durante febrero y octubre. En febrero y marzo, el ASPS se localizó en la parte más austral $\left(\sim 37^{\circ} \mathrm{S}\right)$ y lejana del continente $\left(\sim 108^{\circ} \mathrm{W}\right)$, mientras que en mayo, cuando se observaron las menores intensidades, se localizó en la parte más norteña $\left(\sim 26^{\circ} \mathrm{S}\right)$ y cercana al continente $\left(\sim 86^{\circ} \mathrm{W}\right)$ (fig. 3). 

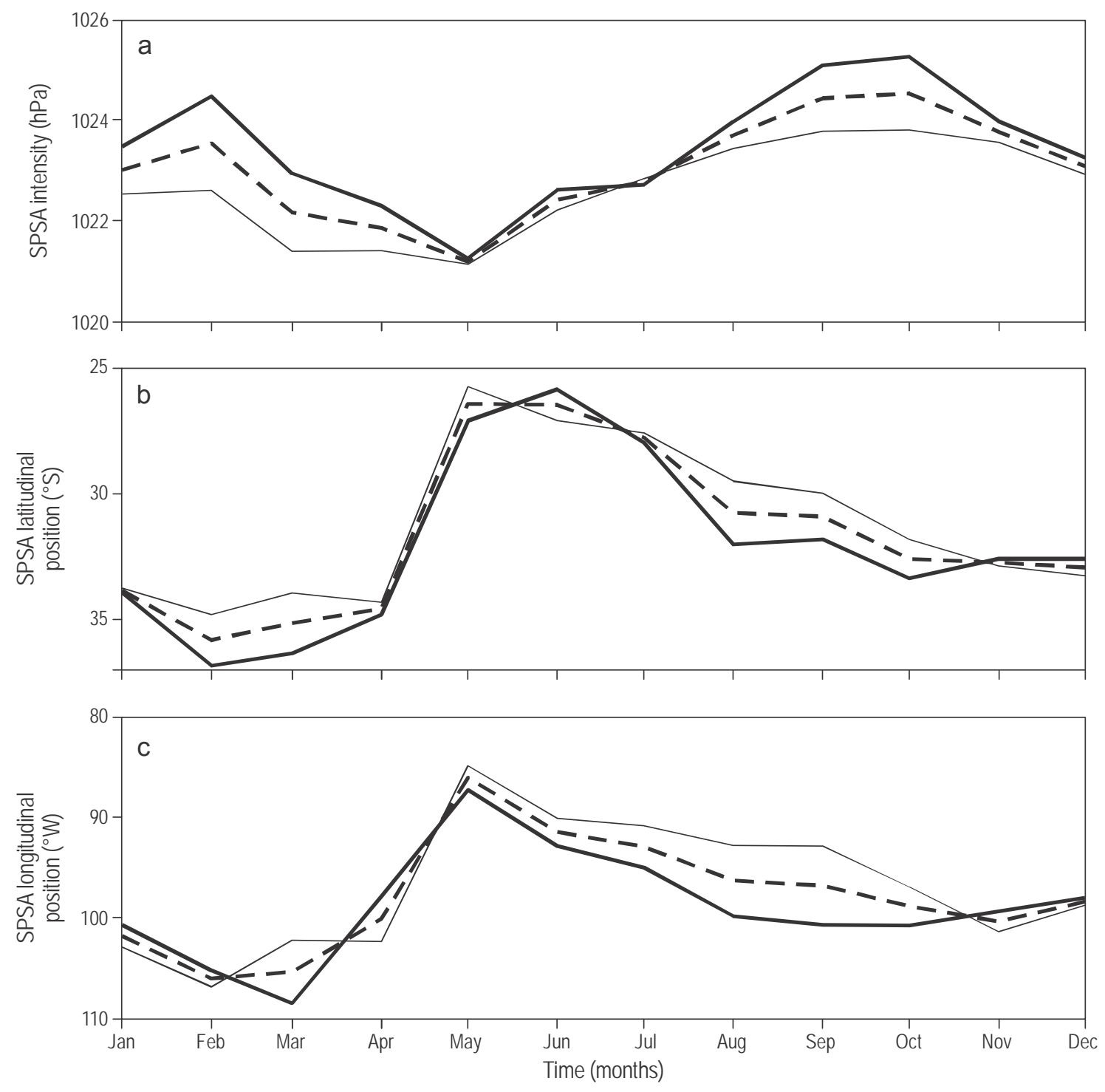

Figure 3. Climatology of the (a) intensity, (b) latitudinal position, and (c) longitudinal position of the Southeast Pacific Subtropical Anticyclone (SPSA): warm phase (thin line), cold phase (thick line), and normal phase (dashed line).

Figura 3. Climatologías de la (a) intensidad, (b) posición latitudinal y (c) posición longitudinal del Anticiclón Subtropical del Pacífico Sudeste (SPSA): fase cálida (línea delgada), fase fría (línea gruesa) y fase normal (línea discontinua).

oceanic area $(R<-0.8)$, to the northwest of the center of the SPSA (fig. 5b). In the EOF analysis, the first temporal and spatial mode was very similar to the results obtained with the correlation analysis (figure not shown).

The correlation analysis between the representative interdecadal AP series and the interdecadal PDO series showed an inverse relationship (fig. 6a). The main source of interdecadal variability over the area was the PDO, with $R=-0.70$, which explains $49 \%$ of the decadal variance. The result was not significant $(R=0.01)$ when it was related to the interdecadal SAM series. However, a six-year time lag (fig. 6a) produced a direct relationship, with $R=0.63$, which corresponds to $40 \%$ of the decadal variance, indicating that the SAM changes preceded those of the SPSA.

\section{Variabilidad interanual y decadal del centro del Anticiclón Subtropical del Pacífico Sudeste y su relación con la Oscilación Decadal del Pacífico}

En general, se observó una relación inversa entre la intensidad del ASPS y la ODP: cuando la intensidad del ASPS se incrementó, la ODP estuvo en su fase fría y viceversa $(R=-0.45)$ (fig. 4). Al contrario, se observó una correlación directa entre la posición latitudinal del centro del ASPS y la ODP: cuando el centro del ASPS tendió a dirigirse hacia el ecuador, la ODP se encontró en su fase positiva y viceversa $(R=-0.32)$ (fig. 4). Además, se encontró una relación entre la posición latitudinal y longitudinal del centro del ASPS: cuando éste se desplazó hacia el sur también lo hizo 

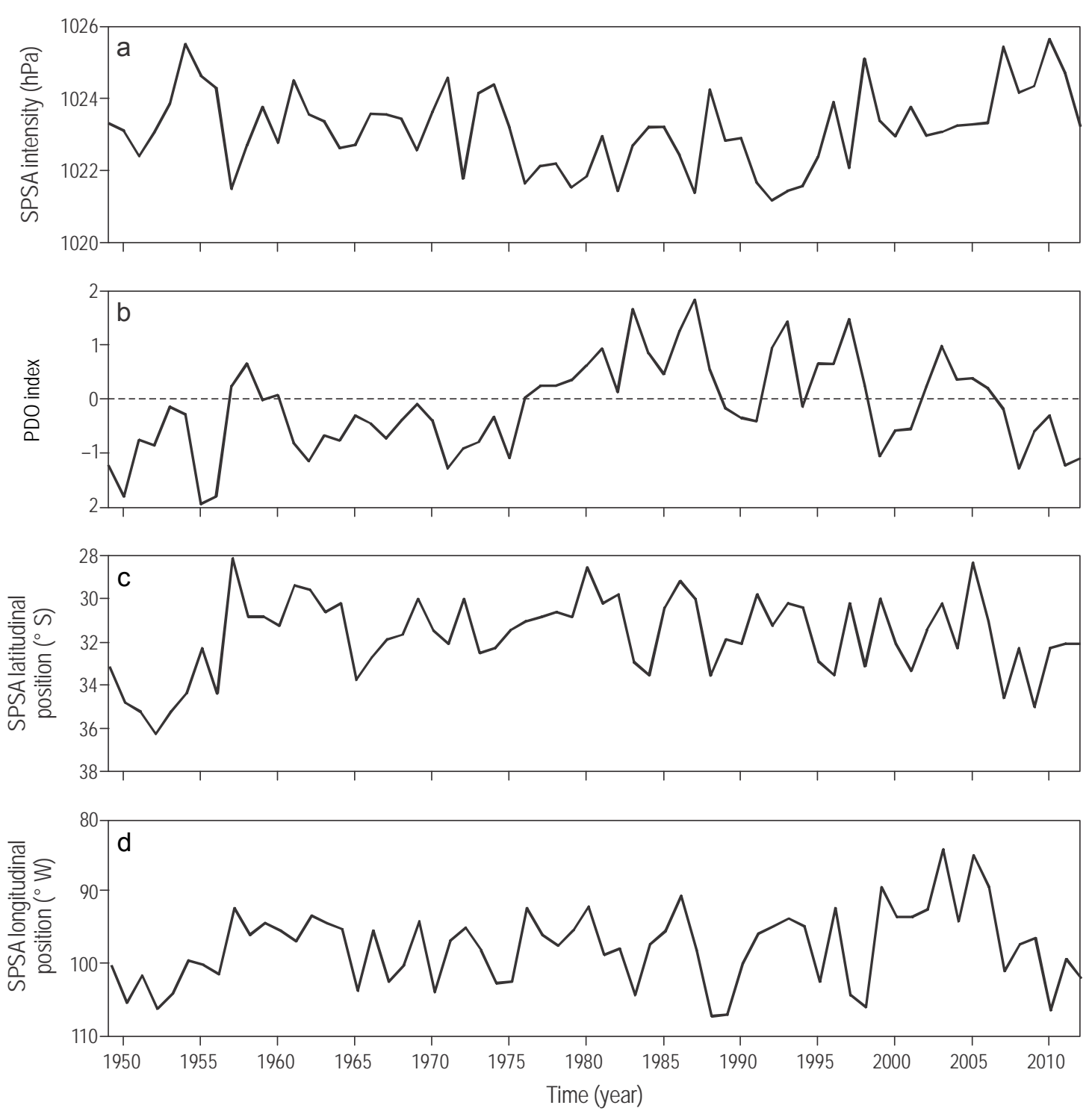

Figure 4. Annual time series of the (a) intensity of the Southeast Pacific Subtropical Anticyclone (SPSA), (b) Pacific Decadal Oscillation (PDO) index, (c) latitudinal position of the SPSA, and (d) longitudinal position of the SPSA.

Figura 4. Series de tiempo anuales de (a) la intensidad del Anticiclón Subtropical del Pacífico Sudeste (SPSA), (b) el índice de la Oscilación Decadal del Pacífico (PDO), (c) la posición latitudinal del SPSA y (d) la posición longitudinal del SPSA.

The spatial structure of the correlation analysis between the interdecadal AP field and the interdecadal PDO series was similar to that observed at the interannual scale. The best negative correlations were obtained to the southwest and north of the SPSA center $(R<-0.8)$. Nonetheless, there were small nearshore areas northward of $38^{\circ} \mathrm{S}$ and southward of $45^{\circ} \mathrm{S}$ that showed positive correlations (fig. 6b). An analysis of this same pressure field in which the warm and cool PDO phases were averaged produced a similar result, that is, a generalized decrease (increase) in AP during the warm (cool) PDO phase (figure not shown). As this lag occurred between AP and SAM, a spatial correlation analysis was performed between the six-year-delayed interdecadal AP hacia el oeste $(R=-0.59)$. Las pruebas de significación determinaron que existieron diferencias significativas entre las fases cálida y fría de la ODP en cuanto a la intensidad $(P<0.001)$, posición latitudinal $(P=0.011)$ y posición longitudinal $(P=0.012)$ del ASPS, lo cual confirma las relaciones encontradas.

Como se mostró, existió una fuerte correlación entre la intensidad y posición del ASPS con la ODP; sin embargo, las señales interanuales y decadales estaban mezcladas $\mathrm{y}$, por tanto, se realizaron los ánalisis de FEO y correlación explicados en la metodología. La correlación entre la serie interanual de PA representativa del campo y la serie interanual del INO presentó una relación inversa $(R=-0.75)$ (fig. 5a). Por lo 
field and the interdecadal SAM series (fig. 6c). The best correlations $(R>0.6)$ were observed to the south and southwest of the SPSA center and in an area close to shore between $33^{\circ}$ and $24^{\circ} \mathrm{S}$; however, some areas with negative correlations were observed to coincide approximately with the positive correlations obtained for the PDO near the coast, as well as a section to the northwest of the SPSA center. In the EOF analysis, the first temporal and spatial mode corresponded to PDO and the second mode to SAM, similar to the results obtained with the correlation analysis. A time lag was also observed in the temporal mode of SAM (figure not shown). tanto, la principal fuente de variabilidad interanual sobre esta área fue ENOS, que explicó el $57 \%$ de la varianza interanual. La estructura espacial del análisis de correlación entre el campo de PA interanual y la serie interanual del INO mostró una relación inversa en toda el área, excepto una pequeña zona localizada al sur de $48^{\circ} \mathrm{S}$. ENOS afectó principalmente a la zona oceánica $(R<-0.8)$, localizada al noroeste del centro del ASPS (fig. 5b). En el análisis de FEO, el primer modo temporal y espacial fue muy parecido a los resultados obtenidos con el análisis de correlación (figura no mostrada).

El análisis de correlación entre la serie interdecadal de PA representativa del campo y el índice interdecadal de la ODP
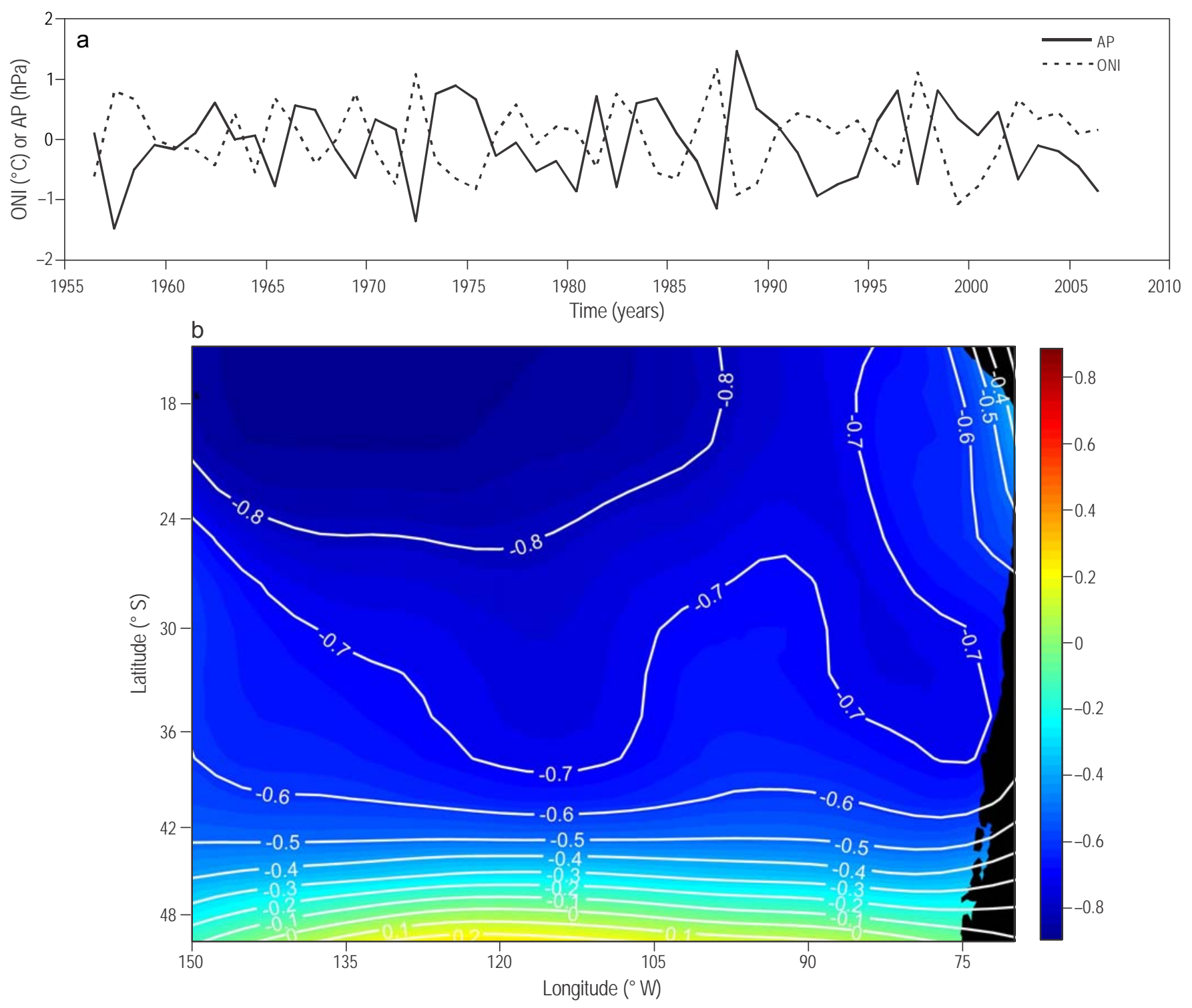

Figure 5. (a) Interannual time series of the representative sea-level air pressure (AP) of the analyzed field and the Oceanic Niño Index (ONI). (b) Spatial structure of the correlation between each interannual series of the AP field and the interannual series of ONI.

Figura 5. (a) Series de tiempo interanuales de la presión del aire a nivel del mar (AP) representativa del campo analizado y del Índice Oceánico El Niño (ONI). (b) Estructura espacial de la correlación entre cada una de las series interanuales del campo de AP y la serie interanual del ONI. 


\section{Impact of the Pacific Decadal Oscillation on the seasonal cycle of the Southeast Pacific Subtropical Anticyclone}

The seasonal cycle of the SPSA was maintained during both phases of the PDO, but its intensity was greater during the cool phase than during the warm phase. In general, during the warm (cool) PDO phase the SPSA tends to move northward (southward) and closer (farther) from shore relative to its climatology. In the first four months of the year, the intensity of the SPSA increased by $\sim 1.5 \mathrm{hPa}$ during the cool PDO phase and there was a southward shift of $\sim 2^{\circ}$ relative to the warm phase. Between May and July the SPSA did not vary much in position and intensity between both PDO phases. From August to October, during the cool phase, the intensity increased again by $\sim 1.5 \mathrm{hPa}$ and the SPSA moved southward $\left(\sim 2^{\circ}\right)$ and offshore $\left(\sim 8^{\circ}\right)$ relative to the warm phase (fig. 3 ).

\section{Southeast Pacific Subtropical Anticyclone and its relation to SST off north-central Chile}

The SPSA intensification anomalies showed an increasing trend of $0.0113 \mathrm{hPa}$ per month (1.36 hPa per decade) between 2000 and 2012, whereas the SST anomalies showed a decreasing trend of $0.0016{ }^{\circ} \mathrm{C}$ per month $\left(0.19{ }^{\circ} \mathrm{C}\right.$ per decade) (fig. 7).

The movement of the SPSA (pressure field) mainly affects the wind stress intensity and direction that may eventually augment coastal upwelling due to an increase in offshore Ekman transport and negative Ekman pumping (Ekman suction). Both processes could explain the observed decrease in SST. The Ekman transport and pumping anomalies were therefore analyzed (fig. 7). Between 2000 and 2012, offshore Ekman transport and Ekman suction tended to increase at a rate of $0.00005 \mathrm{~m}^{2} \mathrm{~s}^{-1}$ per month $\left(0.006 \mathrm{~m}^{2} \mathrm{~s}^{-1}\right.$ per decade) and $0.0016 \mathrm{~m} \mathrm{~d}^{-1}$ per month $\left(0.192 \mathrm{~m} \mathrm{~d}^{-1}\right.$ per decade), respectively.

Although we determined that SST decreased significantly along the coast of north-central Chile, the areas where these changes were most drastic needed to be identified. We therefore analyzed the spatial trend of SST and of the variables that could be responsible for that effect (fig. 8). SST tended to decrease along all the coast, but it decreased notably (more than $0.6^{\circ} \mathrm{C}$ per decade) at $32^{\circ}-31^{\circ} \mathrm{S}, 23^{\circ}-27^{\circ} \mathrm{S}$, and $20^{\circ}-17^{\circ} \mathrm{S}$. Offshore Ekman transport tended to increase only to the south of $33^{\circ} \mathrm{S}$ and was strong at $37^{\circ}-38^{\circ} \mathrm{S}$ (more than $0.15 \mathrm{~m}^{2} \mathrm{~s}^{-1}$ per decade). Ekman suction tended to increase along most of the coast but especially at $37^{\circ}-33^{\circ} \mathrm{S}$ and in two small cells around $39^{\circ} \mathrm{S}$ and $29^{\circ} \mathrm{S}$, where it increased more than $0.15 \mathrm{~m} \mathrm{~d}^{-1}$ per decade.

\section{DISCUSSION}

\section{Seasonal variability of the Southeast Pacific Subtropical Anticyclone}

Several studies have addressed the seasonal migration of SPSA (e.g., Taljaard 1972, Batteen et al. 1995, Strub et al. presentó una relación inversa (fig. 6a). La principal fuente de variabilidad interdecadal sobre esta área fue la ODP, con un $R=-0.70$, que explicó el $49 \%$ de la varianza decadal. El resultado no fue significativo $(R=0.01)$ cuando se relacionó con la serie interdecadal del índice del MAS. Sin embargo, se observó un desfase de seis años (fig. 6a) que produjo una relación directa, con un $R=0.63$, que se corresponde con el $40 \%$ de la varianza decadal, lo cual indica que los cambios del MAS preceden a los del ASPS.

La estructura espacial del análisis de correlación entre el campo de PA interdecadal y la serie interdecadal del índice de la ODP fue parecida a lo que se mostró a escala interanual. Las mejores correlaciones negativas se obtuvieron hacia el sudoeste y norte del centro del ASPS $(R<-0.8)$. Sin embargo, hubieron pequeñas zonas cerca de la costa hacia el norte de $38^{\circ} \mathrm{S}$ y sur de $45^{\circ} \mathrm{S}$ en las cuales se obtuvieron correlaciones positivas (fig. 6b). Un análisis realizado para este mismo campo de presiones, en donde se promediaron los periodos cálidos y fríos de la ODP, presentó un resultado similar; es decir, se observó un descenso (aumento) generalizado de PA durante la fase cálida (fría) de la ODP (figura no mostrada). Como se observó este desfase entre PA y el MAS, el análisis de correlación espacial se realizó entre el campo de PA interdecadal con el retraso de seis años y la serie interdecadal del índice del MAS (fig. 6c). Las mejores correlaciones $(R>0.6)$ se observaron hacia el sur y sudoeste del centro del ASPS y en una región muy cercana de la costa entre $33^{\circ}$ y $24^{\circ} \mathrm{S}$; sin embargo, también se observaron algunas zonas que tuvieron correlaciones negativas que coincidieron aproximadamente con aquellas correlaciones positivas que se obtuvieron con la ODP cercanas a la costa, además de un sector hacia el noroeste del centro del ASPS. En el análisis de FEO, el primer modo temporal y espacial correspondió a la ODP y el segundo modo al MAS, semejante a los resultados encontrados en el análisis de correlación. En el modo temporal del MAS también se observó un desfase (figura no mostrada).

\section{Impacto de la Oscilación Decadal del Pacífico sobre el ciclo estacional del Anticiclón Subtropical del Pacífico Sudeste}

La estacionalidad del ASPS se mantuvo durante ambas fases de la ODP, sin embargo, la intensidad del ASPS fue mayor durante la fase fría que durante la fase cálida. En general, durante la fase cálida (fría) de la ODP, el ASPS tiende a dirigirse hacia el norte (sur) y más cerca (lejos) de la costa respecto a su climatología. En los primeros cuatro meses del año, durante la fase fría de la ODP, se observó un aumento de $\sim 1.5 \mathrm{hPa}$ en la intensidad del ASPS y un movimiento con dirección hacia el sur de $\sim 2^{\circ}$ con respecto a la fase cálida. Entre mayo y julio, el ASPS no varió mucho en su posición e intensidad entre ambas fases de la ODP. De agosto a octubre, durante la fase fría, nuevamente se observó un incrementó en la intensidad del ASPS de $\sim 1.5 \mathrm{hPa}$ y un 

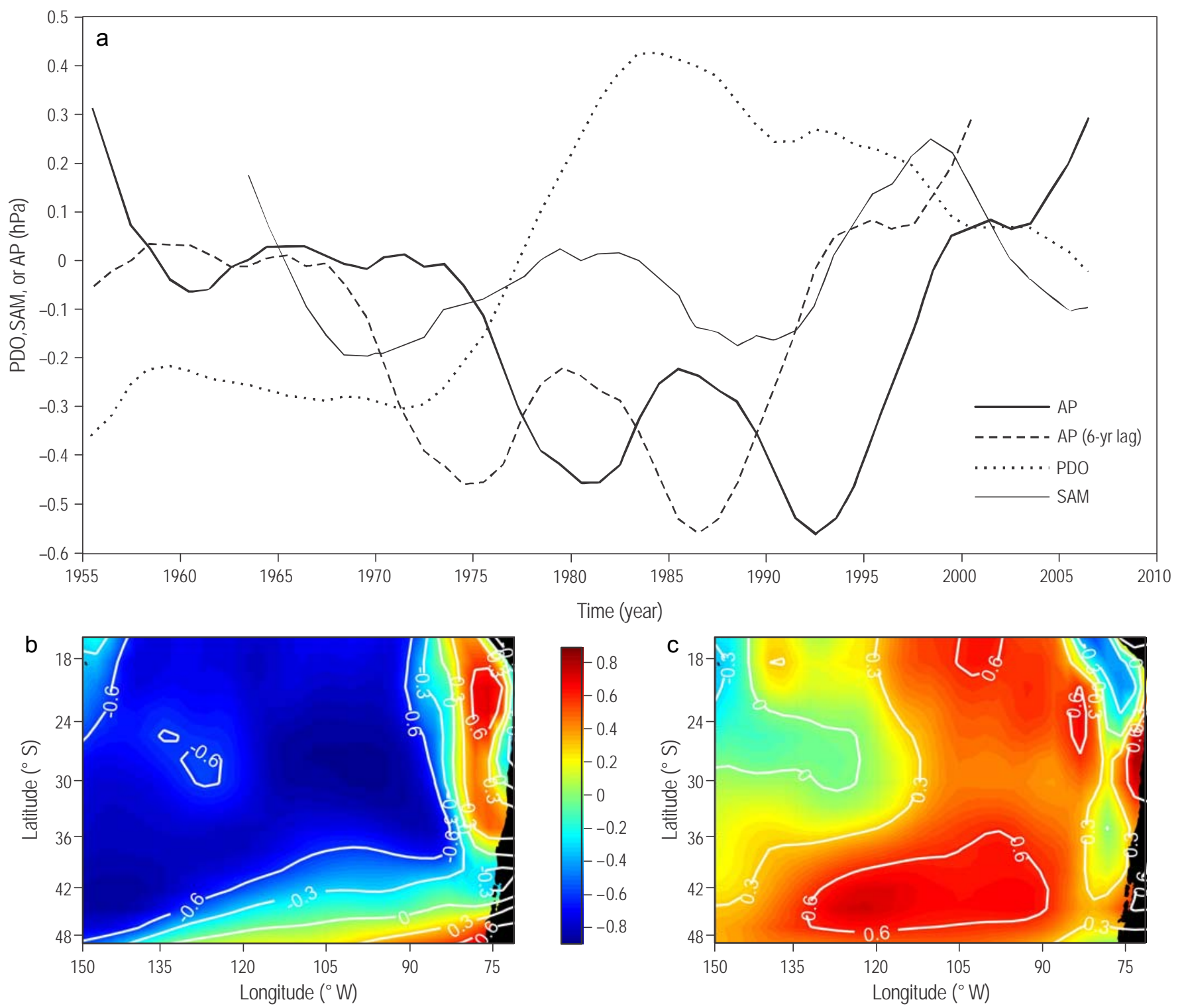

Figure 6. (a) Interdecadal series of the representative sea-level air pressure (AP) of the analyzed field (thick line and dashed line [six-year lag]), PDO/2 index (dotted line), and Southern Annular Mode (SAM) index (thin line). (b) Spatial structure of the correlation between each interdecadal series of the AP field and the interdecadal series of the Pacific Decadal Oscillation (PDO) index. (c) Spatial structure of the correlation between each interdecadal series of the six-year delayed AP field and the interdecadal series of the SAM index.

Figura 6. (a) Series de tiempo interdecadales de la presión del aire a nivel del mar (PA) representativa del campo analizado (línea gruesa y línea discontinua [retrasado seis años]), el índice de la PDO/2 (línea punteada) y el índice del Modo Anular del Sur (SAM) (línea delgada). (b) Estructura espacial de la correlación entre cada una de las series interdecadales del campo de AP y la serie interdecadal del índice de la Oscilación Decadal del Pacífico (PDO). (c) Estructura espacial de la correlación entre cada una de las series interdecadales del campo de PA retrasadas seis años y la serie interdecadal del índice del SAM.

1998, Montecino et al. 2006). They revealed certain differences mainly in regard to the meridional positions (varying in a seasonal range between $25^{\circ} \mathrm{S}$ and $35^{\circ} \mathrm{S}$ ) because different variables (e.g., wind magnitude and direction, AP) and periods were analyzed. In general, however, and in agreement with our results, these studies showed that in summer the SPSA is stronger, further south, and farther from the continent, whereas in winter it is weaker, further north, and closer to the continent. These studies also describe desplazamiento hacia el sur $\left(\sim 2^{\circ}\right)$ y lejos de la costa $\left(\sim 8^{\circ}\right)$ en relación con la fase cálida (fig. 3 ).

\section{Anticiclón Subtropical del Pacífico Sudeste y su relación con la TSM frente a la costa centro-norte de Chile}

Las anomalías de la intensidad del ASPS presentaron una tendencia al aumento de $0.0113 \mathrm{hPa}$ por mes $(1.36 \mathrm{hPa}$ por década) entre 2000 y 2012, mientras que las anomalías de 
seasonal changes, where the monthly variability is lost. In the present study, we observed that the SPSA was less intense, further north, and close to the continent in May, but further to the south and farther from the continent in February, coinciding with the second maximum of the SPSA.

\section{Interannual and decadal variability of the Southeast Pacific Subtropical Anticyclone}

The main source of interannual variability of the pressure field was ENSO, as has also been reported by other authors (Rutllant 2004, Montecinos and Pizarro 2005, Garreaud and Aceituno 2007). ENSO explained $57 \%$ of the interannual variance and primarily affected the intensity of the SPSA, which decreased (increased) during the warm (cool) phase of ENSO, similar to that shown by Rutllant (2004). The area most affected by ENSO, however, was not precisely the SPSA center but the Niño 3.4 region, where an anomalous increase (decrease) occurs mainly in the middle troposphere during the El Niño (La Niña) events when the Walker circulation weakens (intensifies) (Lau and Yang 2003).

Two sources were associated with the decadal variability of the SPSA: PDO, which explained $49 \%$ of the variance, and SAM, which explained $40 \%$ of the variance but showed a time lag. Several studies have shown that the PDO affects both the Northern and Southern hemispheres as this phenomenon operates over the entire Pacific Ocean (Shakun and Shaman 2009, Deser et al. 2010). On the other hand, SAM is a fluctuation that primarily affects the atmospheric circulation at mid- to high-latitudes in the Southern Hemisphere (Gong and Wang 1999, Marshall 2003, Gillett et al. 2006) and is dominated by a decadal variability (Yuan and Li 2008).

The strong correlation between the PDO and the decadal variability of the SPSA confirms previous reports (Montecinos et al. 2003, Shakun and Shaman 2009) that the PDO increases towards the subtropics, precisely in the region where the SPSA is located.

On the other hand, the variability of SAM precedes that of the SPSA by six years. This indicates that there is a time lag but the cause of this is beyond the scope of this research. Nonetheless, this finding helps, to some extent, to improve the decadal-scale predictions and is an indication of a connection between SAM and the subtropical latitudes of the southeastern Pacific.

A strong correlation was observed between the intensity of the SPSA and the PDO, the former strengthening (weakening) during the cool (warm) phase of the PDO and ENSO (Garreaud and Battisti 1999, Pezza et al. 2007). At the decadal scale it was possible to corroborate that, on average, during the cool (warm) phase of the PDO, the SPSA moved southwestward (northeastward) at the same time as it strengthened (weakened), especially from February to March and from September to October (fig. 3). This concurs with that reported by Falvey and Garreaud (2009), who showed
TSM presentaron una tendencia a la disminución de $0.0016^{\circ} \mathrm{C}$ por mes $\left(0.19^{\circ} \mathrm{C}\right.$ por década) (fig. 7$)$.

El movimiento del ASPS (campo de presiones) afecta principalmente a la intensidad y dirección del esfuerzo del viento que eventualmente podrían incrementar el afloramiento costero debido al aumento del transporte superficial de Ekman hacia afuera de la costa y del bombeo negativo (succión) de Ekman. Ambos procesos podrían explicar el decrecimiento de la TSM observado. Por esta razón, se analizaron las anomalías del transporte y bombeo de Ekman (fig. 7). Entre 2000 y 2012, el transporte de Ekman hacia afuera de la costa y la succión de Ekman tendieron a aumentar a un ritmo de $0.00005 \mathrm{~m}^{2} \mathrm{~s}^{-1}$ por mes $\left(0.006 \mathrm{~m}^{2} \mathrm{~s}^{-1}\right.$ por década) y $0.0016 \mathrm{~m} \mathrm{~d}^{-1}$ por mes $\left(0.192 \mathrm{~m} \mathrm{~d}^{-1}\right.$ por década $)$, respectivamente.

Aunque se estableció que la TSM a lo largo de costa centro-norte de Chile disminuyó significativamente, no se conocían las zonas en donde los cambios fueron más drásticos. Por tanto, se realizó un análisis de tendencia espacial de la TSM y de las variables que podrían ocasionar tal efecto (fig. 8). La TSM tendió a disminuir a lo largo de toda la costa, pero el descenso fue drástico (más de $0.6{ }^{\circ} \mathrm{C}$ por década) en $32^{\circ}-31^{\circ} \mathrm{S}, 23^{\circ}-27^{\circ} \mathrm{S}$ y $20^{\circ}-17^{\circ} \mathrm{S}$. El transporte de Ekman hacia afuera de la costa tendió a incrementarse sólo hacia el sur de $33^{\circ} \mathrm{S}$, y fue fuerte en $37^{\circ}-38^{\circ} \mathrm{S}$ (más de $0.15 \mathrm{~m}^{2} \mathrm{~s}^{-1}$ por década). La succión de Ekman tendió a incrementarse a lo largo de casi toda la costa, sobre todo en $37^{\circ}-33^{\circ} \mathrm{S}$ y en dos pequeños núcleos alrededor de $39^{\circ} \mathrm{S}$ y $29^{\circ} \mathrm{S}$, en donde aumentó a más de $0.15 \mathrm{~m} \mathrm{~d}^{-1}$ por década.

\section{DisCUSIÓN}

\section{Variabilidad estacional del Anticiclón Subtropical del Pacífico Sudeste}

Se han realizado varios estudios para establecer la migración estacional del ASPS (e.g., Taljaard 1972, Batteen et al. 1995, Strub et al. 1998, Montecino et al. 2006). Estos estudios mostraron ciertas diferencias principalmente en las posiciones meridionales (variación en un intervalo estacional entre $25^{\circ} \mathrm{S}$ y $35^{\circ} \mathrm{S}$ ) debido a que se utilizaron diversas variables (e.g., magnitud y dirección del viento, PA) y periodos de tiempo. Sin embargo, en general, estos estudios mostraron que el ASPS se encontró más hacia el sur, intenso y lejano del continente en verano y más hacia el norte, débil y cercano al continente en invierno, lo cual concuerda con nuestros resultados. Los trabajos mencionados describen cambios estacionales, en donde se pierde la variabilidad mensual. En el presente trabajo se observó un ASPS menos fortalecido, más hacia el norte y cerca del continente en mayo, pero más hacia el sur y lejano del continente en febrero, coincidente con el segundo máximo del ASPS. 

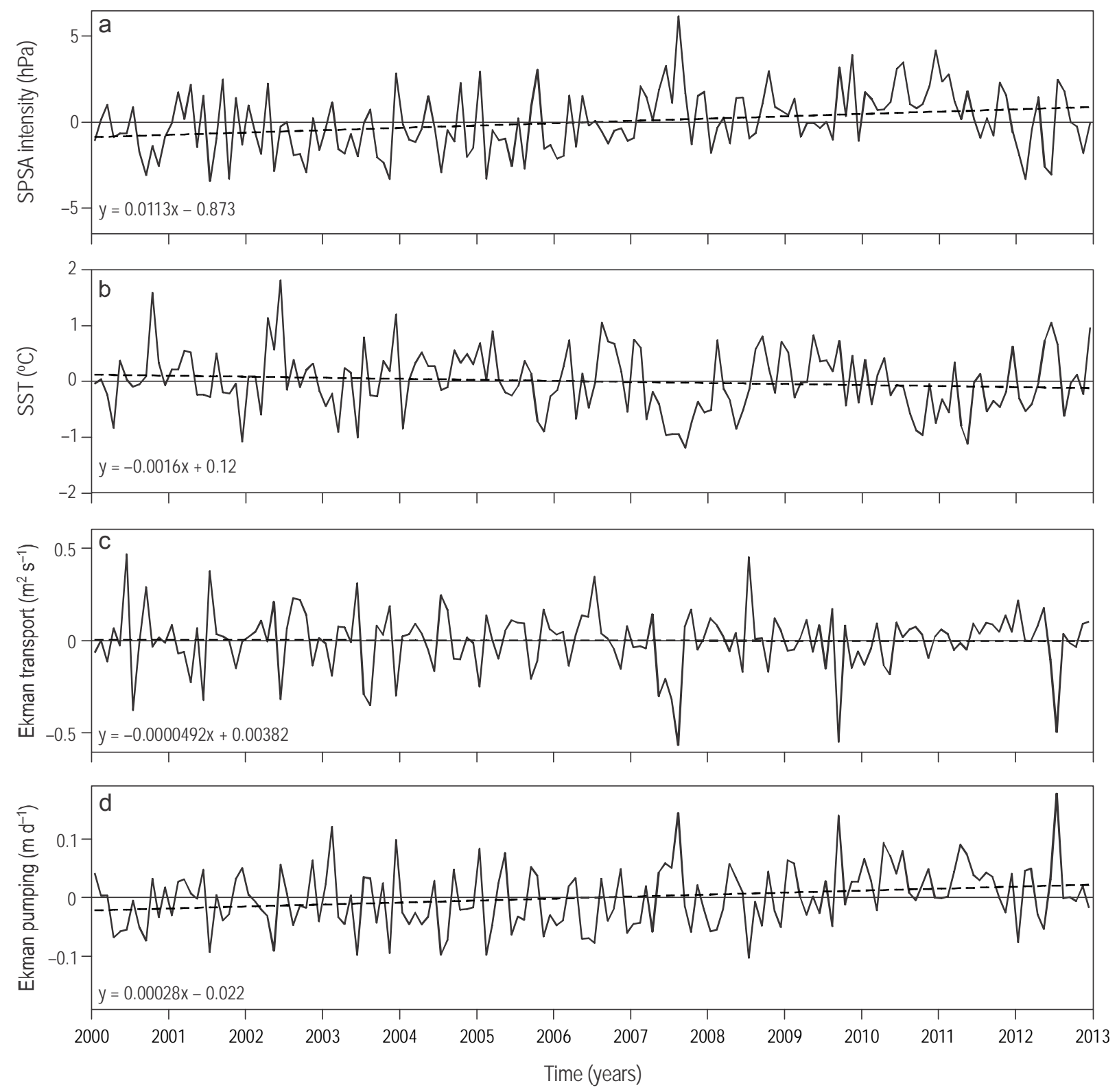

Figure 7. Time series of the monthly anomalies of the (a) intensity of the Southeast Pacific Subtropical Anticyclone (SPSA, air pressure), (b) sea surface temperature (SST), (c) Ekman transport perpendicular to the coastline, and (d) Ekman pumping off north-central Chile. The dotted line represents the trend between 2000 and 2012 of each variable and the fit is shown in the lower left-hand corner.

Figura 7. Series de tiempo de las anomalías mensuales de (a) la intensidad del Anticiclón Subtropical del Pacífico Sudeste (SPSA, presión del aire), (b) la temperatura superficial del mar (SST), (c) el transporte superficial de Ekman perpendicular a la costa y (d) el bombeo de Ekman frente a la costa centro-norte de Chile. La línea recta punteada representa la tendencia entre 2000 y 2012 de cada una de las variables y el ajuste se presenta en la esquina inferior izquierda.

that during the cool PDO phase there was an increase in pressure to the southwest and north of the SPSA, similar to the spatial structure of our first source of decadal variability (fig. 6b). A correlation was also observed between the zonal and meridional positions, which were not high because, in general, during the different phases of the PDO and ENSO, there is an expansion/contraction that does not necessarily involve a shifting of the SPSA center (Miyasaka and Nakamura 2010).

\section{Variabilidad interanual y decadal del Anticiclón Subtropical del Pacífico Sudeste}

La principal fuente de variabilidad interanual del campo de presiones fue ENOS, como ha sido mostrado por otros autores (Rutllant 2004, Montecinos y Pizarro 2005, Garreaud y Aceituno 2007). ENOS explicó el $57 \%$ de la varianza interanual y afectó principalmente la intensidad del ASPS, la cual disminuyó (aumentó) durante la fase cálida (fría) 



Figure 8. Monthly spatial trends between 2000 and 2012 off north-central Chile: (a) sea surface temperature (SST, ${ }^{\circ} \mathrm{C}$ per decade), (b) Ekman transport perpendicular to the coastline $\left(\mathrm{m}^{2} \mathrm{~s}^{-1}\right.$ per decade), and (c) Ekman pumping ( $\mathrm{m} \mathrm{d}^{-1}$ per decade).

Figura 8. Tendencias mensuales espaciales entre 2000 y 2012 frente a la costa centro-norte de Chile: (a) temperatura superficial del mar (TSM, ${ }^{\circ} \mathrm{C}$ por década), (b) transporte superficial de Ekman perpendicular a la costa $\left(\mathrm{m}^{2} \mathrm{~s}^{-1}\right.$ por década) y (c) el bombeo de Ekman ( $\mathrm{m}$ día ${ }^{-1}$ por década).

\section{Southeast Pacific Subtropical Anticyclone and its relation to SST off north-central Chile}

From 1977 to 1998, the PDO was initially in the warm phase and then switched to the cool phase (fig. 4b). Hence, during the latter part of this period, the trends reflected an increase in the intensity of the SPSA and a decrease in SST along the coast of north-central Chile. Falvey and Garreaud (2009) reported a similar increase (1.2 hPa per decade) in AP de ENOS, similar a lo mostrado por Rutllant (2004). Sin embargo, la zona más afectada por ENOS no fue precisamente el centro del ASPS sino la región Niño 3.4, donde existe un anómalo ascenso (descenso) principalmente en la tropósfera media durante los eventos El Niño (La Niña) al debilitarse (intensificarse) la circulación de Walker (Lau y Yang 2003).

Respecto a la variabilidad decadal del ASPS, se encontraron dos fuentes de variabilidad: la ODP, que representó el 
off Easter Island, near the center of the SPSA, between 1979 and 2006. These authors also analyzed air temperatures at coastal stations between $17^{\circ} \mathrm{S}$ and $37^{\circ} \mathrm{S}$ and observed a decrease $\left(0.2^{\circ} \mathrm{C}\right.$ per decade $)$ similar to our SST results.

Though the trends in Ekman transport perpendicular to the coastline and Ekman pumping were explored, it is necessary to perform a heat balance to quantify the decreasing trend of coastal SST between 2000 and 2012. Both processes, which tended to cool during the cool phase of the PDO, can provide evidence of the decrease in SST. When the SPSA strengthens, the pressure gradient between its center and the coastline changes with the consequent modification of the geostrophic wind. Moreover, in the last decade, the SPSA has shifted more towards the southwest (fig. 4c, d). Therefore, the intensification and shifting of the SPSA would increase (decrease) the equatorward (poleward) winds southward (northward) of $33^{\circ} \mathrm{S}$, reducing (increasing) SST as a result of the southward transport of the atmospheric coastal jet observed in figure 1, which is driven by the SPSA (Renault et al. 2009). This effect has been projected in the southern part of our domain under a severe climate change scenario for the end of the 21st century (Garreaud and Falvey 2009, Aiken et al. 2011). The change in the intensification and movement of the SPSA also modifies the wind stress curl, producing upwelling conditions (Ekman suction) and reducing SST along the coast and especially to the south of $33^{\circ} \mathrm{S}$. Likewise, increased equatorward winds also cause a decrease in SST due to turbulent fluxes (proportional to the wind magnitude), especially latent heat flux, whose magnitude and tendency to cool is greater than the sensible heat flux in the area (Garcés-Vargas and Abarca-del-Río 2012). These winds could advect cold waters, decreasing SST even more.

To the north of $33^{\circ} \mathrm{S}$, the decrease in SST can be attributed mainly to the transport of cold waters from the south, from the eastern branch of the South Pacific subtropical gyre (Peru-Chile Current) (Chaigneau and Pizarro 2005). Some authors have reported a strengthening of this gyre between the early 1990s and the early 2000s (Roemmich et al. 2007, Schneider et al. 2007) and this could have been maintained between 2000 and 2012 due to changes in the SPSA. Thomas et al. (2012) did not find a relation between the PDO and SST along the western coast of South America $\left(5^{\circ}-55^{\circ} \mathrm{S}\right)$ between 1998 and 2010 , probably because they considered such a vast area and did not focus on the subtropical western coast where the interdecadal variability is more pronounced (Montecinos et al. 2003).

Though these trends have been related to a strengthening and southwestward shift of the SPSA and the cool phase of the PDO, SAM is most probably also modulating the winds and currents as suggested by Roemmich et al. (2007). However, since SAM explains a smaller percentage of the decadal-scale variance than the PDO and its effect is not as pronounced in subtropical areas, the impact would most likely not be as strong. It will be possible to verify this in the future when more information is available.
$49 \%$ de la varianza, y el MAS que constituyó el $40 \%$ de la varianza pero con un desfase. Varios trabajos han mostrado que la ODP no sólo afecta el hemisferio norte sino también el hemisferio sur y, por tanto es, una oscilación que abarca todo el Pacífico (Shakun y Shaman 2009, Deser et al. 2010). El MAS es una fluctuación que afecta principalmente la circulación atmosférica de las latitudes medias y altas del Hemisferio Sur (Gong y Wang 1999, Marshall 2003, Gillett et al. 2006) y es dominado por una variabilidad decadal (Yuan y Li 2008).

La alta correlación entre la ODP y la variabilidad decadal del ASPS confirmaría lo que ha sido observado por muchos autores (Montecinos et al. 2003, Shakun y Shaman 2009), que la ODP se incrementa hacia los subtrópicos, precisamente en la región donde se encuentra localizado el ASPS.

Se observó que la variabilidad del MAS antecede por seis años a la del ASPS. Esto permite evidenciar que existe un vínculo desfasado cuya causa está fuera del alcance de esta investigación. Sin embargo, este resultado ayuda, en cierta medida, a mejorar los pronósticos a escala decadal y da indicios de una conexión del MAS con latitudes subtropicales del Pacífico sudeste.

Se encontró una muy buena correlación entre la intensidad del ASPS y la ODP, que concuerda con el fortalecimiento (debilitamiento) del ASPS durante las fases frías (cálidas) de ENOS y la ODP (Garreaud y Battisti 1999, Pezza et al. 2007). A escala decadal, se pudo corroborar que en promedio, durante la fase fría (cálida) de la ODP, el ASPS se desplazó hacia el sudoeste (noreste) al mismo tiempo que se intensificó (debilitó), especialmente de febrero a marzo y de septiembre a octubre (fig. 3). Esto concuerda con el estudio realizado por Falvey y Garreaud (2009), quienes mostraron que durante la fase fría de la ODP hubo un mayor incremento de las presiones hacia el sudoeste y norte del ASPS, parecido a la estructura espacial de la ODP encontrada en nuestro estudio (fig. 6b). También se encontró una correlación entre las posiciones zonales y meridionales, que no fueron altas debido a que, en general, durante las distintas fases ENOS y ODP, hay una expansión/contracción que no necesariamente involucra un movimiento del centro del ASPS (Miyasaka y Nakamura 2010).

\section{Anticiclón Subtropical del Pacífico Sudeste y su relación con la TSM frente a la costa centro-norte de Chile}

Desde 1977 a 1998, la ODP estuvo primero en fase cálida y posteriormente pasó a la fase fría (fig. 4b). Durante la última parte, las tendencias reflejaron un aumento de la intensidad del ASPS y un descenso de las TSM a lo largo de la costa centro-norte de Chile. Falvey y Garreaud 2009 observaron un aumento similar (1.2 hPa por década) en PA in situ frente a la isla de Pascua, cercanas al centro del ASPS, entre 1979 y 2006. Los mismos autores analizaron temperaturas del aire de estaciones costeras entre $\operatorname{los} 17^{\circ}$ y $37^{\circ} \mathrm{S}$ y 
In summary, in an analysis of AP, the SPSA was characterized and related to different climate indices. At the interannual scale, ENSO was the dominant force, explaining $57 \%$ of the variance. At the decadal scale, two main sources of variability were identified: PDO, which explained $49 \%$ of the variance, and SAM, which explained $40 \%$ of the variance but with a six-year time lag. During the positive (negative) phase of the PDO, the SPSA tended to weaken (strengthen) and move northeastward (southwestward). The SPSA intensified and shifted southwestward over the past 13 years, during the cool phase of the PDO. This has resulted in a decrease in SST to the south of $33^{\circ} \mathrm{S}$ off central Chile, caused mainly by enhanced offshore Ekman transport and divergence due to Ekman suction, both processes linked to the austral movement of the atmospheric coastal jet.

\section{ACKNOWLEDGMENTS}

This study was financed by the Dirección de Investigación y Desarrollo de la Universidad Austral de Chile. We thank the anonymous reviewer for the constructive criticisms that helped to considerably improve the paper.

English translation by Christine Harris.

\section{REFERENCES}

Aiken CM, Navarrete SA, Pelegri JL. 2011. Potential changes in larval dispersal and alongshore connectivity on the central Chilean coast due to an altered wind climate. J. Geophys. Res. (Biogeosciences) 116.

http://dx.doi.org/10.1029/2011jg001731

Batteen ML, Hu C-P, Bacon JL, Nelson CS. 1995. A numerical study of the effects of wind forcing on the Chile Current System. J. Oceanogr. 51: 585-614. http://dx.doi.org/10.1007/BF02270526

Bentamy A, Fillon DC. 2012. Gridded surface wind fields from Metop/ASCAT measurements. Int. J. Remote Sens. 33: 1729-1754.

http://dx.doi.org/10.1080/01431161.2011.600348

Blanco JL, Carr ME, Thomas AC, Strub PT. 2002. Hydrographic conditions off northern Chile during the 1996-1998 La Niña and El Niño events. J. Geophys. Res. 107(C3): 3-1-3-19. http://dx.doi.org/10.1029/2001jc001002

Carr ME, Strub PT, Thomas AC, Blanco JL. 2002. Evolution of 1996-1999 La Niña and El Niño conditions off the western coast of South America: A remote sensing perspective. J. Geophys. Res. 107(C12): 29-1-29-16. http://dx.doi.org/10.1029/2001jc001183

Chaigneau A, Pizarro O. 2005. Mean surface circulation and mesoscale turbulent flow characteristics in the eastern South Pacific from satellite tracked drifters. J. Geophys. Res. 110(C5). http://dx.doi.org/10.1029/2004JC002628

Chereskin TK, Price JF. 2001. Ekman transport and pumping. In: Steele J, Thorpe S, Turekian K (eds.), Encyclopedia of Ocean Science. Academic Press, London, pp. 809-815.

Croquette M, Eldin G, Grados C, Tamayo M. 2007. On differences in satellite wind products and their effects in estimating coastal upwelling processes in the south-east Pacific. Geophys. Res. Lett. 34(11).

http://dx.doi.org/10.1029/2006GL027538 observaron un descenso $\left(0.2^{\circ} \mathrm{C}\right.$ por década $)$ parecido a nuestro resultado de la TSM.

Si bien se exploraron las tendencias del transporte de Ekman perpendicular a la costa y el bombeo de Ekman, se necesita realizar un balance de calor para cuantificar la tendencia a la disminución de la TSM costera entre 2000 y 2012. Los dos procesos analizados, los cuales tendieron a enfriar durante la última fase fría de la ODP pueden dar indicios de la disminución de la TSM. Al intensificarse el ASPS, el gradiente de presión entre su centro y la costa cambia con la consecuente modificación del viento geostrófico. Además, en la última década, el ASPS se ha dirigido más hacia el sudoeste (figura 4c, d). Por lo tanto, la intensificación y el movimiento del ASPS estarían aumentando (disminuyendo) los vientos hacia el ecuador (polo) hacia el sur (norte) de $33^{\circ} \mathrm{S}$, disminuyendo (incrementando) la TSM debido al traslado hacia el sur del chorro costero atmosférico que se observa en la figura 1, el cual es manejado por el ASPS (Renault et al. 2009). Este mismo efecto ha sido proyectado en la parte sur de nuestro dominio bajo un escenario de cambio climático severo para el final del siglo 21 (Garreaud y Falvey 2009, Aiken et al. 2011). El mismo movimiento y cambio en la intensificación del ASPS también modifica el rotor del viento, lo cual crea condiciones de afloramiento por succión de Ekman y reduce la TSM a lo largo de gran parte de la costa y sobre todo hacia el sur de $33^{\circ} \mathrm{S}$. El incremento de los vientos hacia el ecuador provocaría también una disminución de la TSM por flujos turbulentos (proporcionales a la magnitud del viento), especialmente por flujo de calor latente, cuya magnitud y tendencia a enfriar es mayor que la del flujo de calor sensible en esta zona (Garcés-Vargas y Abarca-del-Río 2012). Estos vientos podrían advectar aguas frías, disminuyendo aún más la TSM.

Hacia el norte de $33^{\circ} \mathrm{S}$, la disminución de la TSM podría ser explicada principalmente por un transporte de aguas frías procedentes del sur, del flanco oriental del giro Subtropical del Pacífico Sur (corriente Perú-Chile) (Chaigneau y Pizarro 2005). Algunos autores han evidenciado un reforzamiento de este giro entre principios de la década de los noventa y principios de la primer década del sigo XXI (Roemmich et al. 2007, Schneider et al. 2007) y esto pudo ser mantenido entre 2000 y 2012 debido a los cambios del ASPS. Thomas et al. (2012) no encontraron una relación entre la ODP y la TSM a lo largo de las costa del oeste de América del Sur $\left(5^{\circ}-55^{\circ} \mathrm{S}\right)$ entre 1998 y 2010 , probablemente debido a que consideraron un área muy amplia y no se centraron en la costa oeste subtropical de Sudamérica en donde la variabilidad interdecadal es más marcada (Montecinos et al. 2003).

Si bien éstas tendencias se han relacionado mejor con una intensificación y un desplazamiento hacia el sudoeste del ASPS y la fase fría de la ODP, lo más probable es que el MAS también esté modulando los vientos y las corrientes como lo sugiere Roemmich et al. (2007). Sin embargo, debido a que el MAS explica un menor porcentaje de la varianza a escala decadal que la ODP y su efecto es menor en zonas subtropicales, se esperaría que el impacto sea mucho 
Deser C, Alexander MA, Xie SP, Phillips AS. 2010. Sea surface temperature variability: Patterns and mechanisms. Annu. Rev. Mar. Sci. 2: 115-143.

http://dx.doi.org/10.1146/annurev-marine-120408-151453

Emery WJ, Thomson RE. 2004. Data Analysis Methods in Physical Oceanography. Elsevier, Amsterdam, 638 pp.

England MH, McGregor S, Spence P, Meehl GA, Timmermann A, Cai W, Gupta AS, McPhaden MJ, Purich A, Santoso A. 2014. Recent intensification of wind-driven circulation in the Pacific and the ongoing warming hiatus. Nature Clim. Change 4: $222-227$.

http://dx.doi.org/10.1038/nclimate2106

Falvey M, Garreaud RD. 2009. Regional cooling in a warming world: Recent temperature trends in the southeast Pacific and along the west coast of subtropical South America (1979-2006). J. Geophys. Res. 114. http://dx.doi.org/10.1029/2008jd010519

Fuenzalida R, Schneider W, Garcés-Vargas J, Bravo L. 2008. Satellite altimetry data reveal jet-like dynamics of the Humboldt Current. J. Geophys. Res. 113(C7). http://dx.doi.org/10.1029/2007jc004684

Garcés-Vargas J, Abarca-del-Río R. 2012. The surface heat fluxes along the eastern Pacific coast from $10^{\circ} \mathrm{N}$ to $40^{\circ} \mathrm{S}$. Aust. Meteorol. Oceanogr. J. 62: 71-82.

Garreaud RD, Battisti DS. 1999. Interannual (ENSO) and interdecadal (ENSO-like) variability in the Southern Hemisphere tropospheric circulation. J. Climate 12: 2113-2123. http://dx.doi.org/10.1175/15200442(1999)012<2113:IEAIEL >2.0.CO;2

Garreaud RD, Muñoz RC. 2005. The low-level jet off the west coast of subtropical South America: Structure and variability. Mon. Weather Rev. 133: 2246-2261. http://dx.doi.org/10.1175/MWR2972.1

Garreaud RD, Aceituno P. 2007. Atmospheric circulation and climatic variability. In: Veblen TT, Young KR, Orme AR (eds.), The Physical Geography of South America. Oxford University Press, New York, pp. 45-59.

Garreaud RD, Falvey M. 2009. The coastal winds off western subtropical South America in future climate scenarios. Int. J. Climatol. 29: 543-554. http://dx.doi.org/10.1002/Joc.1716

Gillett NP, Kell TD, Jones PD. 2006. Regional climate impacts of the Southern Annular Mode. Geophys. Res. Lett. 33(23). http://dx.doi.org/10.1029/2006gl027721

Gong D, Wang S. 1999. Definition of Antarctic Oscillation Index. Geophys. Res. Lett. 26: 459-462. http://dx.doi.org/10.1029/1999g1900003

Hall A, Visbeck M. 2002. Synchronous variability in the Southern Hemisphere atmosphere, sea ice, and ocean resulting from the annular mode. J. Climate 15: 3043-3057. http://dx.doi.org/10.1175/1520-0442(2002)015<3043:Svitsh>2.0.Co;2

Hayward TL. 1997. Pacific Ocean climate change: Atmospheric forcing, ocean circulation and ecosystem response. Trends Ecol. Evol. 12: 150-154. http://dx.doi.org/10.1016/S0169-5347(97)01002-1

Huang RX, Russell S. 1994. Ventilation of the Subtropical North Pacific. J. Phys. Oceanogr. 24: 2589-2605. http://dx.doi.org/10.1175/1520-0485(1994)024<2589:Votsnp >2.0.Co;2

Kalnay E, Kanamitsu M, Kistler R, Collins W, Deaven D, Gandin L, Iredell M, Saha S, White G, Woollen J, Zhu Y, Leetmaa A, Reynolds R, Chelliah M, Ebisuzaki W, Higgins W, Janowiak J, Mo KC, Ropelewski C, Wang J, Jenne R, Joseph D. 1996. The NCEP/NCAR 40-Year Reanalysis Project. Bull. Am. Meteorol. Soc. 77: 437-471.

http://dx.doi.org/10.1175/1520-

0477(1996)077<0437:TNYRP >2.0.CO;2 menor. Esto se podrá verificar en las próximas décadas cuando se tengan mayores registros de información.

En resumen, con base en un análisis de PA, se caracterizó al ASPS y se lo relacionó con diferentes índices climáticos. Se determinó que, a escala interanual, el ENOS fue su principal forzante, explicando el $57 \%$ de la varianza. A escala decadal, se encontraron dos fuentes importantes de variabilidad: la ODP, que explicó el 49\% de la varianza, y el MAS, que explicó el $40 \%$ pero con un desfase de seis años. Cuando la ODP se encontró en su fase positiva (negativa), el ASPS tendió a debilitarse (reforzarse) y a desplazarse hacia el noreste (sudoeste). El ASPS se intensificó y se dirigió hacia el suroeste en los últimos 13 años, durante la fase fría de la ODP. Esto produjo un mayor transporte de Ekman hacia afuera de la costa y una divergencia debida a la succión de Ekman, ambos procesos ligados al movimiento austral del chorro costero atmosférico, lo cual provocó un enfriamiento de la TSM al sur de $33^{\circ} \mathrm{S}$ de la costa central de Chile.

\section{Agradecimientos}

Esta investigación fue financiada por la Dirección de Investigación y Desarrollo de la Universidad Austral de Chile. Se agradece al revisor anónimo por las críticas constructivas que mejoraron considerablemente el presente artículo.

Lau KM, Yang S. 2003. Walker Circulation. In: Holton JR (ed.), Encyclopedia of Atmospheric Sciences. Academic Press, Oxford, pp. 2505-2510.

Mantua NJ, Hare SR. 2002. The Pacific Decadal Oscillation. J. Oceanogr. 58: 35-44. http://dx.doi.org/10.1023/A:1015820616384

Mantua NJ, Hare SR, Zhang Y, Wallace JM, Francis RC. 1997. A Pacific interdecadal climate oscillation with impacts on salmon production. Bull. Am. Meteorol. Soc. 78: 1069-1079. http://dx.doi.org/10.1175/15200477(1997)078<1069:Apicow $>2.0 . \mathrm{Co} ; 2$

Marshall GJ. 2003. Trends in the southern annular mode from observations and reanalyses. J. Climate 16: 4134-4143. http://dx.doi.org/10.1175/15200442(2003)016<4134:Titsam >2.0.Co;2

Miyasaka T, Nakamura H. 2010. Structure and mechanisms of the Southern Hemisphere summertime subtropical anticyclones. J. Climate 23: 2115-2130. http://dx.doi.org/10.1175/2009jcli3008.1

Montecino V, Strub PT, Tarazona J, Chavez FP, Thomas AC, Baumgartner T. 2006. Bio-physical interactions off western South America. In: Robinson AR, Brink KH (eds.), The Sea. Vol. 14A. The Global Coastal Ocean. Harvard Press, Cambridge, MA, pp. 329-390.

Montecinos A, Pizarro O. 2005. Interdecadal sea surface temperature-sea level pressure coupled variability in the South Pacific Ocean. J. Geophys. Res. 110(C8). http://dx.doi.org/10.1029/2004jc002743

Montecinos A, Purca S, Pizarro O. 2003. Interannual-to-interdecadal sea surface temperature variability along the western coast of South America. Geophys. Res. Lett. 30(11). http://dx.doi.org/10.1029/2003GL017345 
Pezza AB, Simmonds I, Renwick JA. 2007. Southern Hemisphere cyclones and anticyclones: Recent trends and links with decadal variability in the Pacific Ocean. Int. J. Climatol. 27: 1403-1419. http://dx.doi.org/10.1002/Joc.1477

Piolle J-F, Bentamy A. 2002. Mean Wind Fields (MWF product) User Manual. Vol. 2: QuikSCAT. C2-MUT-W-04-IF, CERSAT, Plouzané, 47.

Pizarro O, Hormazabal S, González A, Yáñez E. 1994. Variabilidad del viento, nivel del mar y temperatura en la costa norte de Chile. Invest. Mar. 22: 85-101. http://dx.doi.org/10.4067/S0717-71781994002200007

Power S, Casey T, Folland C, Colman A, Mehta V. 1999. Interdecadal modulation of the impact of ENSO on Australia. Clim. Dyn. 15: 319-324. http://dx.doi.org/10.1007/s003820050284

Renault L, Dewitte B, Falvey M, Garreaud R, Echevin V, Bonjean F. 2009. Impact of atmospheric coastal jet off central Chile on sea surface temperature from satellite observations (2000-2007). J. Geophys. Res. (Oceans) 114. http://dx.doi.org/10.1029/2008jc005083

Reynolds RW, Smith TM, Liu C, Chelton DB, Casey KS, Schlax MG. 2007. Daily high-resolution-blended analyses for sea surface temperature. J. Climate 20: 5473-5496. http://dx.doi.org/10.1175/2007JCLI1824.1

Roemmich D, Gilson J, Davis R, Sutton P, Wijffels S, Riser S. 2007. Decadal spinup of the South Pacific subtropical gyre. J. Phys. Oceanogr. 37: 162-173. http://dx.doi.org/10.1175/Jpo3004.1

Rutllant J. 2004. Aspectos de la circulación atmosférica de gran escala asociada al ciclo ENOS 1997-1999 y sus consecuencias en el régimen de precipitación en Chile central. In: Avaria S, Carrasco J, Rutland J, Yáñez E (eds.), El Niño-La Niña 1997-2000: Su efecto en Chile. Comité Oceanográfico Nacional. CONA, Valparaíso, pp. 61-76.

Schneider W, Fukasawa M, Garcés-Vargas J, Bravo L, Uchida H, Kawano T, Fuenzalida R. 2007. Spin-up of South Pacific subtropical gyre freshens and cools the upper layer of the eastern South Pacific Ocean. Geophys. Res. Lett. 34(24). http://dx.doi.org/10.1029/2007GL031933

Shakun JD, Shaman J. 2009. Tropical origins of North and South Pacific decadal variability. Geophys. Res. Lett. 36. http://dx.doi.org/10.1029/2009g1040313

Smith TM, Reynolds RW, Peterson TC, Lawrimore J. 2008. Improvements to NOAA's historical merged land-ocean surface temperature analysis (1880-2006). J. Climate 21: 2283-2296. http://dx.doi.org/10.1175/2007jcli2100.1

Sobarzo M, Bravo L, Donoso D, Garcés-Vargas J, Schneider W. 2007. Coastal upwelling and seasonal cycles that influence the water column over the continental shelf off central Chile. Prog. Oceanogr. 75: 363-382.

http://dx.doi.org/10.1016/j.pocean.2007.08.022
Strub PT, Mesías JM, Montecino V, Rutllant J, Salinas S. 1998. Coastal ocean circulation off western South America. Coastal segment. In: Robinson AR, Brink KH (eds.), The Sea. John Wiley, New York, pp. 273-313.

Taljaard JJ. 1972. Synoptic meteorology of the Southern Hemisphere. In: Newton CW, Van Loon H, National Center for Atmospheric Research (US) (eds.), Meteorology of the Southern Hemisphere. American Meteorological Society, Boston, pp. 139-213.

Talley LD, Pickard GL, Emery WJ. 2011. Descriptive Physical Oceanography: An introduction. Academic Press, Amsterdam; Boston, $555 \mathrm{pp}$.

Thiel M, Macaya EC, Acuña E, Arntz WE, Bastias H, Brokordt K, Camus PA, Castilla JC, Castro LR, Cortés M, Dumont CP, Escribano R, Fernández M, Gajardo JA, Gaymer CF, Gómez I, González AE, González HE, Haye PA, Illanes JE, Iriarte JL, Lancellotti DA, Luna-Jorquera G, Luxoro C, Manríquez PH, Marín V, Muñoz P, Navarrete SA, Pérez E, Poulin E, Sellanes J, Sepúlveda HH, Stotz W, Tala F, Thomas A, Vargas CA, Vásquez JA, Vega JMA. 2007. The Humboldt Current System of northern and central Chile. Oceanogr. Mar. Biol. 45: 195-344. http://dx.doi.org/10.1201/9781420050943

Thomas AC, Strub PT, Weatherbee RA, James C. 2012. Satellite views of Pacific chlorophyll variability: Comparisons to physical variability, local versus nonlocal influences and links to climate indices. Deep-Sea Res. II 77-80: 99-116. http://dx.doi.org/10.1016/j.dsr2.2012.04.008

White WB, Cayan DR. 1998. Quasi-periodicity and global symmetries in interdecadal upper ocean temperature variability. J. Geophys. Res. 103(C10): 21335-21354. http://dx.doi.org/10.1029/98jc01706

Willis JK, Roemmich D, Cornuelle B. 2004. Interannual variability in upper ocean heat content, temperature, and thermosteric expansion on global scales. J. Geophys. Res. 109(C12). http://dx.doi.org/10.1029/2003jc002260

Yáñez E. 1991. Relationships between environmental changes and fluctuating major pelagic resources exploited in Chile (1950-1988). In: Kawasaki T, Tanaka S, Toba Y, Taniguchi A (eds.), Long-term Variability of Pelagic Fish Populations and their Environment. Proceedings of the International Symposium, Sendai, Japan, 14-18 November 1989. Pergamon Press, Oxford, England, pp. 301-309.

Yuan XJ, Li CH. 2008. Climate modes in southern high latitudes and their impacts on Antarctic Sea ice. J. Geophys. Res. 113(C6). http://dx.doi.org/10.1029/2006jc004067

Zhang Y, Wallace JM, Battisti DS. 1997. ENSO-like interdecadal variability: 1900-93. J. Climate 10: 1004-1020. http://dx.doi.org/10.1175/1520-0442(1997)010<1004:Eliv>2.0.Co;2

Received August 2013, accepted September 2014. 